\title{
Vernakulaari verkossa
}

\author{
Vertaisuuden ilmaisemisen digitaaliset ulottuvuudet
}

\author{
Kaarina Koski ja Riikka Turtiainen
}

$\mathrm{D}$ igitaalinen teknologia on avannut uusia väyliä omaehtoiselle ilmaisukulttuurille, jonka suhdetta mediaan ja ammattimaiseen tuotantoon voi tarkastella folkloristiikan näkökulmasta vernakulaarin käsitteen avulla. Vernakulaarilla tarkoitetaan kulttuurien tutkimuksessa kansanomaista tai kansankielistä, omaehtoista, spontaania tai arkista kulttuuria. Termiä on alettu kehittää 2000-luvulle tultaessa nykyaikaan sopivaksi vastineeksi kansa-alkuisille määritelmille, jotka perustuvat vanhastaan jakoon eliitin ja maalaisrahvaan tai valtakulttuurin ja paikalliskulttuurin välillä. Nykypäivän vernakulaari ei ole enää yhteiskunnan alimpien kerrosten kulttuuria, joka viittaa menneisyyteen, vaan se nousee instituutioiden katveista ja uusilta digitaalisilta alustoilta ja tarjoaa myös malleja institutionaalisille käytännöille ja sisällöille (Noyes 2012, 15-16, 19). Vernakulaari määritellään yleisesti instituutioiden ulkopuoliseksi tai valtakulttuuriin nähden alisteiseksi tai marginaaliseksi kulttuuriksi, joka voi olla tukahdutettua mutta jolla on vastakulttuurisena ja suurta yleisöä edustavana myös voimaa ja auktoriteettia. Nykyaikana, kun valta- ja vastakulttuurien väliset rajat ovat monimutkaistuneet, myös institutionaaliset ja vernakulaarit toimijuudet ovat kiinteässä dialogissa toisiinsa tai hybridisiä, kummastakin asemasta ammentavia. (Howard 2008a; 2008b). Vernakulaaria voidaan lähestyä yhä enemmän tyylilajina tai rekisterinä, jolla asemoidaan itseä suhteessa muihin ihmisiin. Näin määriteltynä vernakulaarin käsitteen avulla voidaan tarkastella, millaisista asemista kulttuurin tuottamiseen ja yhteiskunnalliseen keskusteluun osallistutaan. Kehitämme tässä vernakulaarin käsitettä eteenpäin tarkastelemalla sitä rekisterinä, jolla ilmaistaan vertaisuutta.

Yhteiskunnassamme vernakulaarin kommunikaation muodot kuten arkikeskustelut, itseilmaisu, kuluttaminen ja verkostoituminen hyödyntävät luontevasti digitaalista teknologiaa. Älypuhelimet ovat yksilön jatkeita: ne ovat muistin ja henkilökohtaisen repertuaarin laajennusosa ja sellaisena osa kulttuurista kompetenssia. (Heimo 2013, 54; Heimo ja Koski 2014.) Teknologia ja digitaaliset ympäristöt tukevat sitä yhteiskunnallista kehitystä, jossa pysyvät rakenteet ja paikkasidonnaisuus menettävät merkitystään, yhteisöt ovat vaihtuvia ja sosiaalinen identiteetti ja yhteenkuuluminen ovat jatkuvassa muutoksessa. Keskitetyt instituutiot menettävät auktoriteettiaan yksilöllistä valintaa edustaville väljille verkostoille ja ryhmittymille. (Bauman 2002, 20-23; ks. myös Bauman 1992, 193-195; Kangaspunta 2011.) Digitaalisen teknologian vernakulaari haltuunotto on merkinnyt myös sitä, että omaehtoisessa ilmaisussa voi hyödyntää, varioida ja jäljitellä uskottavasti kaupallisia sisältöjä kuten populaarikulttuurin kuvastoja. Tuottajan ja kuluttajan välinen roolijako hämärtyy, ja 
institutionaalinen ja vernakulaari ovat toisiinsa dialogisessa suhteessa ja sekoittuvat. (Bruns 2010, 125; Howard 2008a; Turtiainen ja Östman 2009, 340.)

Tässä artikkelissa tarkastelemme vernakulaarin kulttuurin ja rekisterin asemia digitaalisissa ympäristöissä ja erityisesti niiden hyödyntämistä ammattimaisissa kehyksissä. Teoreettisina lähtökohtina ovat vernakulaarin hybridisyys (Howard 2008a, 2008b) eli institutionaalisen ja vernakulaarin yhdistyminen sosiaalisessa mediassa sekä vernakulaari auktoriteetti (Howard 2013, 2019). Esittelemme taustaksi vernakulaari-käsitteen käyttöönottoa ja kehitystä digitaalista kulttuuria tarkastelevassa folkloristiikassa ja retoriikassa. Tarkastelemme sitten vernakulaarin hybridisyyttä ja vernakulaarin auktoriteetin muotoutumista kolmen tapausesimerkin kautta, joissa hybridisyys toteutuu eri tavoin. Ensimmäinen tapaus esittelee omaehtoisen ja ammattimaisen tuotannon välistä dialogia ja molemminpuolista lainaamista. Esimerkkinä siitä on epäonnistuneita kakkuja koskeva viihde, jossa vernakulaari, taidon ja taitamattomuuden väliseen eroon perustuva huumori siirtyy nettifoorumeilta institutionaalisiin kehyksiin. Toinen tarkastelee populistisen ammattipoliitikon vernakulaaria auktoriteettia, joka perustuu hybridiseen toimijuuteen. Tarkastelun kohteena ovat Perussuomalaisen puolueen puheenjohtajien erilaiset strategiat vernakulaarin auktoriteetin rakentamisessa ja erityisesti Jussi Halla-ahon emojien käyttö. Kolmas esimerkki esittelee omaehtoisen ja kaupallisen toiminnan rajalla tasapainottelevia somevaikuttajia, jotka säilyttävät uskottavuutensa vernakulaareina auktoriteetteina samalla kun kaupallinen yhteistyö tekee heidän toiminnastaan ammattimaista. Esimerkkien tarkastelu asettuu tässä folkloristiikan, retoriikan, digitaalisen kulttuurin ja mediatutkimuksen risteyskohtaan.

\section{Vernakulaarin ulottuvuuksia}

Ongelmallisen ja ideologisesti värittyneen kansa-käsitteen korvaavaa vernakulaarin käsitettä on käytetty kansainvälisessä kulttuurien tutkimuksessa satunnaisesti 1960-luvulta ja yhä lisääntyvästi 1970-luvulta lähtien (Howard 2008a, 493-494; Noyes 2012, 17). Vernakulaarin määrittelyssä digitaalisen folkloren osalta vaikutusvaltaisimpana voi pitää yhdysvaltalaisen Robert Glenn Howardin ajatuksia, jotka kehittävät eteenpäin aiempia näkökulmia vernakulaarista yleisenä ja alisteisena. Yleinen vernakulaari on tavallista ja kaikkien tavoitettavissa olevaa verrattuna vain harvojen ulottuvilla olevaan korkeakulttuuriin. Se on yhteinen, valtadiskursseista erillinen kulttuurinen resurssi, jolla on voimaa yleisen mielipiteen ja arkijärjen lähteenä. Alisteisena vernakulaarina on tarkasteltu sorrettujen ja marginaalisten ryhmien kuten rahvaan tai vähemmistöjen kulttuuria. Alisteinen vernakulaari on nähty 1980-luvulta lähtien vastakulttuurisena identifikaationa ja voimauttavana diskurssina, jolla alakulttuurit ja alistetut kansanryhmät luovat positiivista identiteettiä valtakulttuurin ulkopuolelle asettuvina. (Howard 2008a, 493-495; Noyes 2012, 18.) Vastakulttuurisen diskurssin ikiaikaisia keinoja on esittää ulkoryhmän kuten valtakulttuurin edustajat omaa ryhmää tyhmempinä tai moraalisesti heikompina (esim. Knuuttila 1992, 71-77). Vernakulaari diskurssi ei voi kaikissa tilanteissa olla luontevasti sekä yleistä mielipidettä osoittava että vastakulttuurinen (Ingraham 2013, 14) vaan niitä voi tarkastella vernakulaarin erillisinä ulottuvuuksina.

Kolmas keskeinen vernakulaarin luonnehdinta kulttuurien tutkimuksessa on ollut paikallisuus. Se viittaa paikalliseen kielimuotoon, kokemukseen, ajattelutapaan ja paikallisiin intresseihin, joilla on paikallista relevanssia. Paikallisena vernakulaarin on katsottu keskittyvän kotipiiriin erillisenä julkisesta elämästä, julkista diskurssia ylläpitävästä tekniikasta tai akateemisen eliitin teorioista. (McLaughlin 1996, 6; Noyes 2012, 17-18.) Paikallisuutta on 
tarkasteltu myös rajoittuneisuutena ja tietämättömyytenä muusta kuin omasta yhteisöstä (Knuuttila 1992, 70). Howard (2008a, 493) onkin sisällyttänyt paikallisuuden alistettuun vernakulaariin ja institutionaalisten keskustelujen ulkopuolisuuteen. Alistetun ohella tai sijaan paikallisuus voi kuitenkin olla arkista, täydentävää tai jopa institutionaalisen toiminnan taustaresurssi, ja digitalisoitumisen myötä siihen kytkeytyy hyvinkin myös globaalin ja institutionaalisen osallistumisen mahdollisuus. Nykyaikana vernakulaarin paikallisuus tulee ymmärtää maantieteellisen paikallisuuden sijaan yhteisö- ja diskurssikohtaisena. Siihen liittyy myös erityisyys verrattuna yleiseen, standardoituun ja massatuotettuun (Howard 2008b, 194). Sellaisena siihen liittyy positiivisia aitouden mielikuvia, joita instituutiot eivät voi tavoittaa.

Howard on uudistanut aiempia sääty- ja luokkayhteiskuntaa kuvaavia vernakulaarin määritelmiä muistuttamalla, että etenkin digitaalisissa ympäristöissä vernakulaari ja institutionaalinen sekoittuvat toisiinsa monin tavoin ja yksilö voi toimia eri rooleissa tilanteesta riippuen. Hän korostaa hybridisyyttä vernakulaarin olennaisena ominaisuutena tarkoittaen, että vernakulaarilla on aina kiinteä yhteys institutionaaliseen kuten ammattimaisesti tuotettuihin ja virallisiin (kuten valtiollisiin, kaupallisiin, kirkollisiin, poliittisiin ynnä muihin) järjestelmiin, tuotteisiin, arvoihin tai toimintoihin. Kulttuuristen sisältöjen tuotannossa vernakulaari ja institutionaalinen ovat monimutkaisessa riippuvuussuhteessa ja tuotanto on sekoittunutta. Howard esittää hybridisyyden kuuluneen termiin jo sen alkulähteillä antiikin Roomassa: verna merkitsi kotiorjaa, joka talossa syntyneenä hallitsi sekä äidinkielensä että klassisen latinan ja tunsi sekä roomalaiset käytännöt että orjien elämän. Hänellä oli pääsy kahden eri kulttuurin tietoon, jolloin hänellä oli sekä instituution tuoma että sen ulkopuolisuuteen viittaava toimijuus. (Howard 2008a, 495-498; 2008b, 204-205.) Vastaavasti digitaalisessa ympäristössä toimiva aikalaisemme voi toimia milloin virallisessa roolissa työpaikkansa edustajana, milloin taas arkiroolissaan tai valitsemissaan nettiyhteisöissä niissä käyttämillään identiteeteillä.

Howard lähestyy vernakulaaria tietoisena erottautumisena instituutioista, joka tapahtuu esimerkiksi genren tai tyylin valinnalla. Erottautuminen on olennaista erityisesti silloin, kun tuotanto tai itseilmaisu tapahtuu institutionaalisissa kehyksissä kuten kaupallisilla palvelimilla. Erillisyyttään asemoidessaan vernakulaari samalla osallistuu institutionaaliseen, jolloin puhdasta vernakulaaria ei ole, vaan pelkästään eriaisteista hybridisyyttä. (Howard 2008a, 498-499; 2008b, 195, 203.) Howardin lähestymistapa perustuu alistettuun vernakulaariin, jossa erottuminen on itsetietoista. Yhteiskunnassa, jossa eliitin ja rahvaan välistä jyrkkää eroa ei ole, virallisen ja vernakulaarin välisen suhteen voi myös nähdä jatkumona, jossa on kyllä ääripäät mutta joka ei edellytä institutionaalisen ja vernakulaarin välille selvää statuseroa (Ingraham 2013, 13). Nähdäksemme instituutioiden ulkopuolella voidaan yhtä hyvin suuntautua instituutioita kohti kuin ilmaista erillisyyttä. Sellaista on esimerkiksi omaehtoinen ja vernakulaareja ilmaisutapoja hyödyntävä mutta kaupallisesti kunnianhimoinen somevaikuttajuus, jota tarkastellaan jäljempänä. Hybridisyys toteutuu myös sulautumalla ja samastumalla.

Vaikka sosiaalinen media on lisännyt ja tehnyt näkyvämmäksi vernakulaarin ja institutionaalisen välistä monipuolista vuorovaikutusta ja sekoittumista, se ei ole uusi ilmiö (Howard 2008a, 498; 2008b, 203). Eri kansankerrosten sekä pienen ja suuren tradition välillä on aina ollut molemminpuolista vuorovaikutusta, vaikka folkloristeilla on ollut tapana kuoria aineistoista pois kirjallisia ja kirkollisia vaikutteita (esim. Kallio ym. 2017, 13). Tässä katsannossa folkloristien aiempi tapa lähestyä kansankulttuuria autenttisena ja puhtaan kansanomaisena 
sekä sarvioida sekoittuneita muotoja epäaitona (ks. esim. Bendix 1997, 7-11) näyttäytyy väliaikaisena ideologisena ekskursiona vernakulaari-termin käyttöhistoriassa. Kysymys aitoudesta on kyllä läsnä edelleen, mutta nyt vernakulaarin diskurssin sisällä.

Digitaalisen vernakulaarin hybridisyys ei merkitse pelkästään sitä, että suuri yleisö omaksuu yhä enemmän kaupallisia ja kansainvälisiä elementtejä omaan kulttuuriinsa. Kaupalliset ja poliittiset toimijat pyrkivät entistä tiiviimmin seuraamaan ja ennakoimaan tavallisten ihmisten mieltymyksiä. Instituutioiden edustajat kuten poliitikot hyödyntävät vernakulaareja ilmaisuja retorisena keinona vedotakseen suureen yleisöön. Vernakulaarin tyylilajin käyttöönotto kertoo, kenelle ilmaisu on osoitettu. (Ono ja Sloop 2002, 12-13; Ingraham 2013, 13.) Tässä suhteessa vernakulaaria voi lähestyä rekisterinä (ks. myös Bronner 1992, 9-10), jolla ilmaistaan vertaisuutta ja instituutioista erillistä asemaa. Rekisteri ilmaisee viestinnässä tai muussa kulttuurisessa toiminnassa ilmenevää tilannekohtaista variaatiota, joka liittyy toimijan tai viestijän erilaisiin rooleihin, tavoitteisiin ja sosiaalisiin sidoksiin. Rekisterin valintaan vaikuttavat siis viestintäkanava, aihepiiri, kohderyhmä ja viestijän tavoitteet. (Halliday 1979, 32-34; Koski 2016, 127-128). Vernakulaarin tarkasteleminen rekisterinä painottaa, että kyseessä on tilannekohtaisesti omaksuttu positio ja sitä ilmentävä, tilanteeseen sopiva tyylilaji tai retoriikka. Rekisterin vaihtoa tapahtuu arkielämässä jatkuvasti, kun siirrytään seurueesta tai roolista toiseen tai halutaan lähestyä toisenlaista kohderyhmää. (Haapalainen ym. 2015, 211-214.) Rekisteriin voi sisältyä kielen ja kuvailmaisun lisäksi myös kulutusvalintoja, joilla ilmaistaan yhteisyyttä tai identifioitumista johonkin ryhmään, elämäntyyliin ja asenteeseen (Agha 2011). Vernakulaarilla rekisterillä ilmaistu vertaisuus voi olla todellista, kun saman ryhmän jäsenet viestivät vapaamuotoisesti keskenään, tai näennäistä, kun valtakulttuuria edustava toimija puhuttelee yleisöä vernakulaaria rekisteriä hyödyntäen. Vernakulaarin rekisterin taitava hallinta tuo uskottavutta ja vernakulaaria auktoriteettia viestijän asemasta riippumatta.

\section{Osallistuva käänne ja vernakulaarin hybridisyys}

Digitaalisissa ympäristöissä tuotannon sekoittumisen edellytyksenä on ollut teknologian vernakulaari haltuunotto. Digitalisoitumisen myötä aiemmin vain ammattikäytössä ollut tuotantoteknologia yhdentyi: nyt ääntä, kuvaa, filmiä ja tekstiä saattoi editoida yhdellä laitteella digitaalisessa muodossa ja sisältöjä pystyi jakamaan internetissä. Nämä laitteet alkoivat yleistyä myös kotikäytössä 1900-luvun lopulla. (Fagerjord 2010, 187-188.) Sosiaalisen median myötä yksilöt ovat pystyneet julkaisemaan tuotantoaan ilman että tuotantoyhtiöt valitsisivat, ketkä pääsevät ääneen ja missä muodossa. Vaikka huomio on internetissä edelleen keskittynyttä osittain rahallisen panostuksen ehdoilla, tilannetta on luonnehdittu voimasuhteiden muutokseksi mediassa ja kulttuurin demokratisoitumiseksi. Voidaan väittää, että tavalliset ihmiset ovat ottaneet median omiin käsiinsä ja täyttäneet sen vernakulaarilla kulttuurilla. Ammattituottajien monologista siirryttiin dialogiseen suhteeseen ja institutionaalisen ja vernakulaarin sisällön uudenlaiseen sekoittumiseen. (Benkler 2006, 10, 15, 233 237; Cross 2011, 6; Howard 2008a, 501; Howard 2008b, 194; Jenkins 2006, 132.)

Mediatutkimuksessa tätä muutosta on nimitetty osallistuvaksi käänteeksi (engl. participatory turn) (Jenkins 2006, 290). Osallistuminen on laaja yhteiskunnallinen ilmiö, joka ulottuu kansalaisvaikuttamisesta wiki-pohjaisten tietokantojen kokoamiseen ja henkilökohtaiseen digijulkaisemiseen (Delwiche ja Henderson 2013, 3-4). Osallistuminen on omaehtoista ja käyttäjälähtöistä ja pohjautuu kulttuurisiin, sosiaalisiin ja henkilökohtaisiin tavoitteisiin. Se 
voidaan erottaa interaktiivisuudesta, joka voi olla palveluntuottajan tai vaikkapa pelisuunnittelijan ohjailemaa aktiviteettia. Kaupallisten tuotteiden kohdalla osallistuminen voi olla tuotteen käyttämistä luovasti toisella tavalla kuin mihin se oli suunniteltu, esimerkiksi videoanimaatioiden tekemistä pelikoneilla. (Benkler 2006, 295; Jenkins 2006, 132-133; Koski 2011, 24.)

Kaupallisten elementtien hyödyntäminen itseilmaisussa on tyypillisin vernakulaarin hybridisyyden muoto. Digitaalisessa ympäristössä yksilö on riippuvainen instituutioiden hallitsemista tieto- ja sähköverkoista, hän käyttää kaupallisia laitteistoja ja ohjelmistoja sekä hyödyntää ilmaisunsa kuvastoina varsin usein ammattituotantoon perustuvia kuvia ja hahmoja. Etenkin tällaisissa institutionaalisissa kehyksissä vernakulaari tyyli syntyy tietoisena etääntymisenä virallisesta, ja sitä merkitään tyylillisin tai sisällöllisin keinoin. (Howard 2008, 498-499.) Vernakulaarissa diskurssissa genret, sisällöt, käytännöt ja tavoitteet poikkeavat institutionaalisista. Sosiaalisen median vernakulaareja genrejä ovat tyypillisesti arki- ja vertaisviestinnässä käytetyt ja omaehtoista ilmaisua välittävät genret kuten tekstiä ja kuvaa yhdistävät kuvamakrot, reaktiokuvat, emojit, vitsit, blogit tai fanifiktio ja -taide sekä (audio) visuaalisuuden ja mobiiliteknologioiden roolin entisestään korostuessa esimerkiksi selfie-kulttuuri ja katoaviksi tarkoitetut somesisällöt.

Voidaan puhua vernakulaarista appropriaatiosta, kun yleisö ottaa kaupallisen kuvaston omaan käyttöönsä ja tekee sillä mitä haluaa. Vaikka kaupalliset kuvastot kuten elokuvien ja TV-sarjojen tunnetuiksi tekemät hahmot ovat yleisintä uuden merkityksen ja käytön saavaa aineistoa, myös yksityishenkilön internetiin lataamat sisällöt voivat meemiytyä ja päätyä intensiiviseen kulttuuriseen kiertoon uudelleen ja uudelleen merkityksellistettyinä. Appropriaatio-termiä käytetään yleensä poliittissävyisissä diskursseissa osoittamassa valtakulttuurin harjoittamaa kulttuurista riistoa. Käytämme sitä tässä neutraalina terminä mutta myös osoittaaksemme vernakulaarien käytäntöjen lisääntynyttä valtaa. Näkemys valta- ja kansankulttuurin välisestä suhteesta on jyrkästi muuttunut sitten 1900-luvun alun ja gesunkenes Kulturgut -tyyppisen ajattelun, jonka mukaan vaikutteet laskeutuvat eliitiltä rahvaalle eikä rahvas luo uutta vaan omaksuu kulttuurisia innovaatioita yrittämällä jäljitellä eliitin kulttuuria (ks. Bendix 1997). Korkeakulttuurin tai massatuotetun kulttuurin uudelleentulkintaa omaan käyttöön on tarkasteltu sittemmin kiistämisen kulttuurina, joka sekin pelkistää kansankulttuuria reaktioksi hegemoniaa kohtaan (Knuuttila 1992, 71-78). Kulttuurinen lainaaminen ja viittaaminen perustuu monenlaisiin omaehtoisiin vaikuttimiin, joista vastarinta voi olla yksi mutta jossa oman sosiaalisen identiteetin luomisella suhteessa ympäröivään kulttuuriin on yhä suurempi rooli etenkin sosiaalisen median alustoilla.

Appropriaatio-termi viittaa myös siihen, että toiminta voi olla tekijänoikeuksien kannalta ongelmallista. Kaupalliset toimijat ovat aiemmin haastaneet esimerkiksi faneja oikeuteen tuotteidensa omavaltaisesta ja vääränlaisesta käytöstä, joskin myöhemmin fanien toiminta on alettu tulkita myös kaupallisia tavoitteita edistävänä (Jenkins 2006, 138). Internetissä hybridistä vernakulaaria tuotantoa julkaisevat henkilöt ovat sittemmin alkaneet lisätä esimerkiksi videoihinsa merkinnän, etteivät omista sisältöjen tekijänoikeuksia. He puolustavat oikeuttaan julkaisemiseen myös sillä, etteivät he saa toiminnasta kaupallista hyötyä. Internet-yhteisöissä hyväksytään yleisesti kaupallisten, kaikkien jo valmiiksi tuntemien aineistojen versiointi ja uudelleentulkinnat. Vernakulaarin vertaistuotannon hyödyntämistä sen sijaan pidetään herkemmin varastamisena. (Koski 2011, 21.) Vertaiseltaan anastava varastaakin juuri sitä sosiaalisen median valuuttaa, joka on alkuperäiselle julkaisijallekin tärkeää eli sosiaalista pääomaa ja vernakulaaria auktoriteettia. 
Vernakulaarin hybridisyys ei ole pelkästään digitaalisen ympäristön luoma ilmiö. Vastakulttuurinen rekisteri voi syntyä esimerkiksi yhdistämällä valtakulttuuriin sisältyviä tyylejä ja arkisia hyödykkeitä odottamattomalla tavalla kuten 1970-luvun brittiläisessä punk-pukeutumisessa, jossa koulupuvun osiin yhdistettiin WC-istuimen ketjuja ja hakaneuloja ja kosmetiikka otettiin uudenlaiseen maskuliiniseen käyttöön. Alakulttuurinen rekisteri ilmaisi erottumista valtavirtaisesta kulttuurista. (Agha 2011, 47.)

Omaehtoiseen vernakulaariin ilmaisuun liittyy sisällöllisiä säännönmukaisuuksia. Vernakulaari sisältö perustuu ensinnäkin omiin merkityksenantoihin kuten kaupallisesti tuotettujen sisältöjen tulkitsemiseen ja käyttämiseen vaihtoehtoisella tavalla. Internetissä sellaista voi olla valtavirtaisia sukupuolirooleja kyseenalaistava fanitaide tai uutiskuvien muokkaaminen humoristisiksi tai poliittista kritiikkiä sisältäviksi meemeiksi. Toiseksi vernakulaari sisältö ilmentää ja käsittelee paikallisesti relevantteja kysymyksiä, huolia ja ilonaiheita. Kolmanneksi se perustuu yhteisöjen kulttuuriseen kompetenssiin eli vernakulaarin rekisterin hallintaan: esimerkiksi meemiytyneiden mallihahmojen tai sanontojen käyttö ja tulkinta edellyttää usein meemikulttuurin laajojen intertekstuaalisten viitteiden tuntemusta. Osallistuminen vernakulaariin diskurssiin ja oman sosiaalisen identiteetin muokkaaminen esimerkiksi meemejä jakamalla ja kommentoimalla ovat digitaalisessa ympäristössä tavallisia vernakulaareja käytäntöjä, joiden tavoitteet ovat omaehtoisia, vaikka niissä hyödynnetään institutionaalisia kehyksiä ja kuvastoja.

Hybridisyyttä syntyy myös niin, että institutionaalinen tai ammatillinen toimija haluaa hyödyntää vernakulaareja kuvastoja tai käytäntöjä. Artikkelimme analyysiesimerkit käsittelevät nimenomaan tällaisia tapauksia. Digitaalisessa kulttuurissa näkyvyyttä saaneella vernakulaarilla ilmaisulla on painoarvoa, jonka kaupalliset ja muut institutionaaliset toimijat ottavat huomioon. Osallistuvan käänteen myötä mediateknologia on taipunut palvelemaan vernakulaareja tavoitteita, kun se massamedian aikakaudella palveli vain institutionaalisia päämääriä (Howard 2008b, 192). Vedotessaan yleisöön kaupalliset ja muut institutionaaliset toimijat pyrkivät vaihtelevalla menestyksellä hyödyntämään vernakulaareja genrejä ja tyylejä. Ilmiö ei liity pelkästään digitaaliseen ympäristöön. Edellä mainittu punk-tyyli, kuten moni muukin omaehtoinen irtiotto, on muokattu kaupallisesti valtavirtaiseen tuotantoon (Agha 2011, 47). Instituution kaupallisia tai poliittisia päämääriä ajavia toimia ei mielletä aidosti vernakulaareiksi, ja epäaidoiksi koetut yritykset jäljitellä vernakulaaria diskurssia kääntyvät usein itseään vastaan. Niin voi käydä esimerkiksi jos kaupallinen yhtiö perustaa vapaan keskustelun sallivan blogin mutta alkaa kuitenkin moderoida sitä eli poistaa yrityksen tavoitteisiin sopimattomia puheenvuoroja. (Esim. Howard 2008b 197-199.) Joskus institutionaalista auktoriteettia edustava taho voi onnistuakin, kuten Verohallinto, joka voitti videollaan vuoden parhaan somepresenssin palkinnon Grand One 2019 -gaalassa. Viranomaisen Facebook-sivulla julkaistulla videolla Verohallinnon verkkotoimittaja kuiskii verotuspäätöksen periaatteita YouTuben suosittuja ASMR-videoita' jäljitellen. (Rautio 2019; ks. myös Turtiainen 2019.) Tällä kertaa institutionaalinen taho onnistui omaksumaan vernakulaarit käytännöt niin hyvin, että "kansa" hyväksyi näennäisellä vertaisuudella leikittelyn jopa siitä huvittuen. Vernakulaarin hybridisyydessä kyse ei siis ole pelkästään siitä, että tavalliset ihmiset hyödyntävät kaupallisia tuotteita omaehtoisessa ilmaisussaan. Suhde on kaksisuuntainen ja monikerroksinen. 


\section{Kakkumokat: vernakulaarista huumorista ammattimaiseksi tuotannoksi}

Tyylien ja aineistojen lainailu vernakulaarin ja kaupallisen toiminnan välillä on molemminpuolista ja etenee toisinaan lainausten ja merkityksenantojen ketjuksi. Tarkastelemme seuraavaksi epäonnistuneisiin kakkuihin liittyvää huumoria esimerkkinä kulttuurituotannon hybridisyydestä, jossa vernakulaari käytäntö ja asenne muokataan osaksi kaupallista tuotantoa. Yksityisten ihmisten ottamat kuvat epäonnistuneista leivonnaisista ovat suosittua selattavaa internetissä. Suomalaiset lähettävät erilaisia epäonnistumisiaan esimerkiksi "Ei menny niinku Strömsössä" -nimiseen Facebook-ryhmään ja julkaisevat niitä omilla kanavillaan sosiaalisessa mediassa. Mitä irvokkaammalta kakku näyttää, sitä enemmän riemua se herättää. Kaikkia hirveitä kakkuja ei voi tulkita epäonnistumisiksi, vaan osa niistä on mitä ilmeisimmin tarkoituksella sellaisiksi leivottuja. Huumorintutkimuksessa tällaista huumoria on selitetty inkongruenssiteorialla, jonka mukaan poikkeamat ihanteista, odotuksista ja normeista huvittavat meitä (esim. Morreall 1983, 15-18). Erityisen suosituiksi ovat tulleet kuvaparit, joissa esimerkiksi reseptin mukana ollut mallikuva ja itse tehty versio esitetään rinnakkain otsikkoparilla "Expectations" ja "Reality" tai otsikolla "Nailed it!" - nappisuoritus! Kakkukuvaparit myötäilevät tyypillistä meemien kaavaa. Vastakkainasettelut on todettu yhdeksi suosituimpien internetmeemien keskeisimmistä piirteistä (Knobel ja Lankshear 2007, 215-216; ks. myös Shifman, 2014).

Kuvien suosio on saanut kaupalliset sivut kokoamaan niitä julkaisuiksi. Hakusanalla "failed cakes" löytyi 23.10.2019 Googlen hakukoneen kautta noin 25600000 tulosta ja hakusanalla "epäonnistuneet kakut" 698000 tulosta. Molemmissa hauissa kaikki ensimmäisillä sivuilla olevat osumat olivat kaupallisia sivuja, joille on koottu internetistä löydettyjä kuvia.
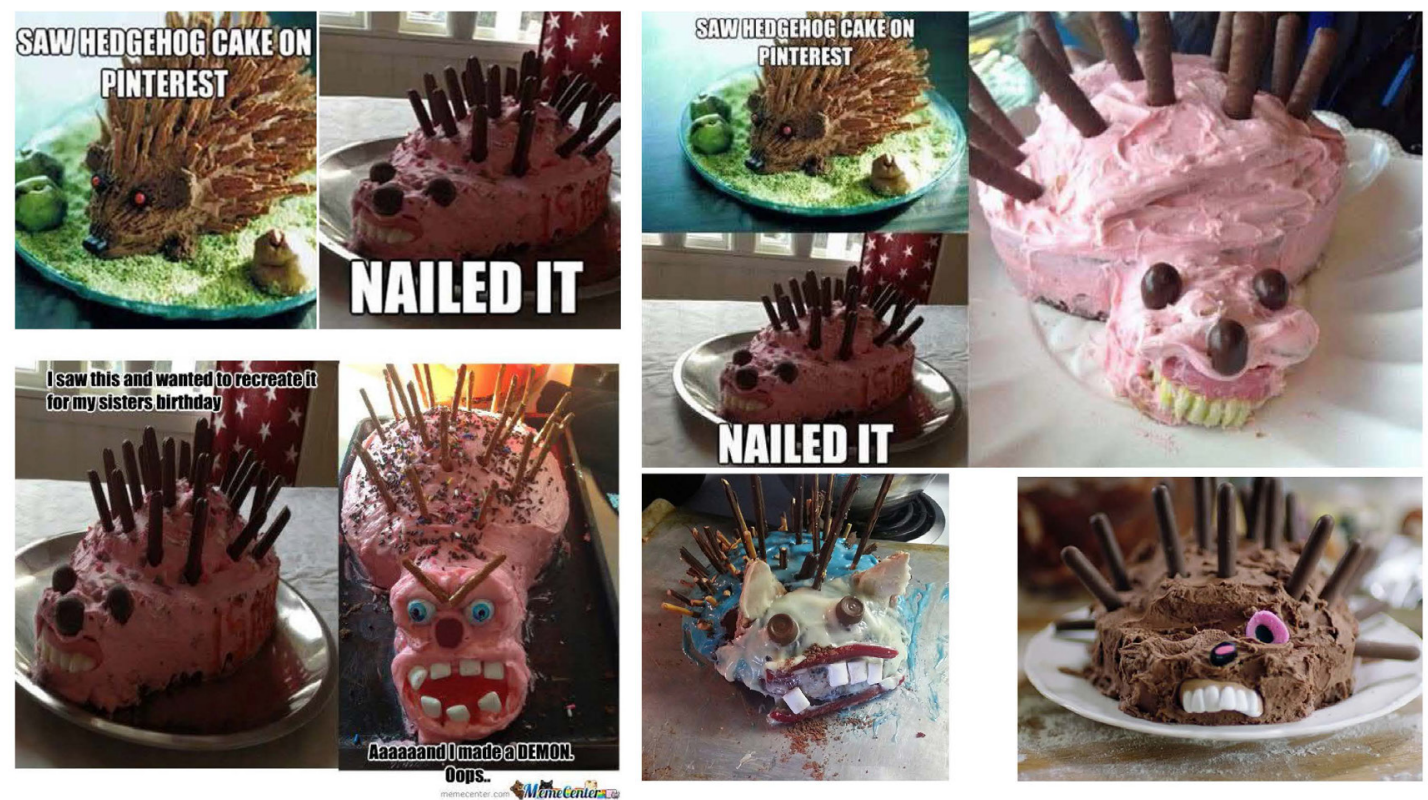

Kuva 1. Epäonnistuneista siilikakuista on tullut meemi. Ihanteen ja ei-niin-ihanteellisen todellisuuden rinnastaminen toisiinsa on klassinen huumorin rakennusaine ja yksi suosituimpia meemienkin kaavoja. Siilikakun mallia ja itse leivottua kakkua esittelevät meemit eivät välttämättä ole leipojien itsensä tekemiä vaan hyödyntävät internetistä valmiiksi löytyviä kuvia. Irvokkaiden kakkujen saama suosio inspiroi myös panemaan pahemmaksi kotikeittiössä. Hammasrivillä koristeltua "Nailed it"-kakkua on imitoitu runsaasti. 


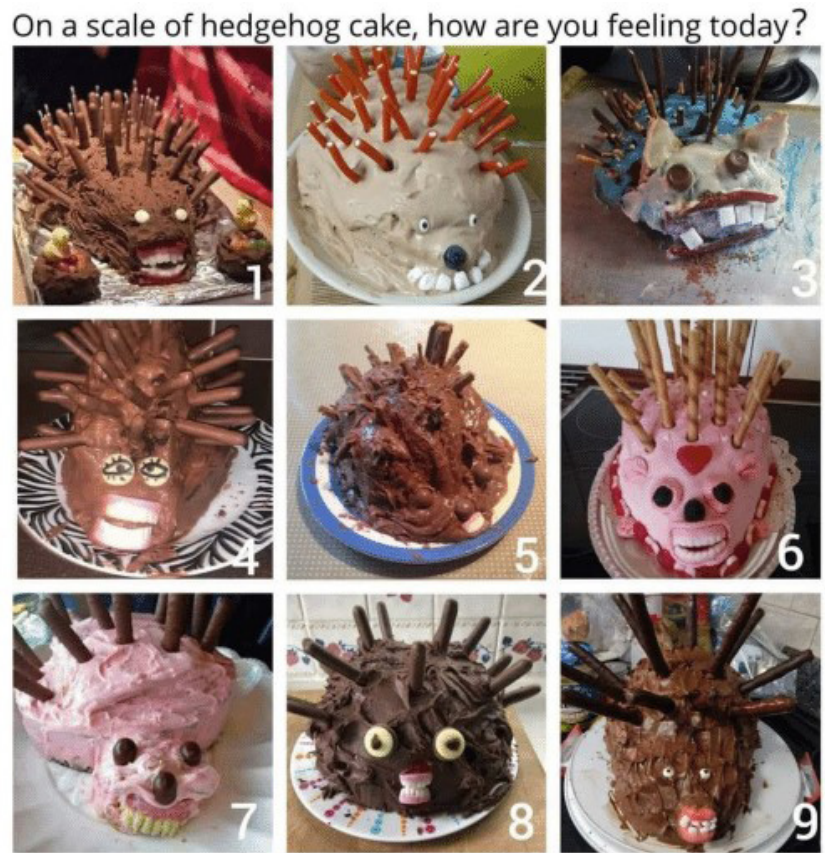

Kuva 2. Siilikakkuskaalalla mitattuna, miten menee tänään? Kuvasarja edustaa suosittua ja runsaasti varioivaa "How are you feeling today?" -meemiä. Meemin ideana on, että kaikki kuvat esittävät esimerkiksi samaa tunnettua henkilöä eri tilanteissa tai hassahtaneita kissoja. Siilikakkujen päätyminen tähän meemiin viittaa siihen, että ne ovat jo valmiiksi laajalti tunnettu ilmiö.

Otsikoina oli esimerkiksi "18 of the Best Cake Fails that Will Make You Laugh So Hard"2 tai "16 kakkua, jotka epäonnistuivat niin pahasti, että lapsetkin alkoivat itkemään"3. Suomessa tällaiset kokoelmat sisältävät usein kansainvälisesti kiertäviä kakkukuvia, mutta lehdet ovat myös pyytäneet lukijoita lähettämään kuvia pieleen menneistä kakuista ja luvanneet palkkion. ${ }^{4}$ Omaehtoista tuotantoa kootaan siis kaupallisten julkaisujen sisällöiksi. Kakkumokat on alettu ottaa huomioon myös leivontapiirien institutionaalisella tasolla. Leivontafoorumeilla on jo omia osastojaan niille (Baking Forums -sivuston Cake Fails) tai TV:n leivontaohjelma voi kehottaa katsojia yrittämään kotona TV:ssä näkemiään suorituksia ja lähettämään ohjelman nettisivulle kuvia (The Great British Bake-Off). Nämä ovat ohjattuja interaktiivisuuden muotoja, joissa yleisön luovuutta kanavoidaan sitä varten luotuun kehykseen.

Kuvien lisäksi myös leipominen on edennyt ammattimaiseen viihdetuotantoon. Vuonna 2018 aloitettiin Yhdysvalloissa sittemmin myös Eurooppaan levinnyt kaupallinen tosi-TVsarja "Nailed It!", jossa leivontataidottomat maallikot yrittävät jäljitellä ammattilaisten tekemiä luomuksia. ${ }^{5}$ Ohjelma on yhdistelmä kilpailua ja kohellusta, jossa varsinaisena päämääränä on kakkujen naurettavuus. Vaikka voittajaksi valitaan parhaan näköinen ja makuinen kakku, leipomiseen annetaan tarkoituksella aivan liian vähän aikaa ja mallikakuissa on koristeina ihmis- ja eläinhahmoja, joiden kehnous on vielä koomisempaa kuin pelkkä kakkujen vinous tai suttuisuus. Ihanteiden ja todellisuuden väliseen ristiriitaan perustuva komiikka edellyttää selvää rajaa ammattilaisen ja kotileipurin välille, mutta "Nailed it!" -sarja välttää asiantuntijuuden korostamista. Juontaja metelöi karnevalistisessa tyylilajissa, ottaa selfieitä

\footnotetext{
2 Awesome inventions. https://www.awesomeinventions.com/cake-fails/ (katsottu 23.10.2019)

3 Herkkusuut. https://www.herkkusuut.com/16-kakkua-jotka-epaonnistuivat-niin-pahasti-etta-lapsetkin-alkoivat-itkemaan/ (katsottu 23.10.2019)

4 "Piristä kaikkien päivää ja lähetä kuva omasta pieleen menneestä leivonnaisestasi kuvagalleriaamme täällä. Kun osallistut 3. toukokuuta mennessä ja jätät yhteystietosi, olet mukana kivan palkinnon arvonnassa." https://www.menaiset.fi/artikkeli/ruoka/ei-mennyt-niin-kuin-stromsossa-laheta-kuva-leivontamokastasi. "Innostuitko leipomaan mutta homma ei mennyt kuin Strömsössä? Lähetä kuvasi osoitteeseen [- -]! Palkitsemme törkeimmät tortut elokuvalipuilla." https://www.iltalehti.fi/fiidifi/a/2015042419575389 (katsottu 23.10.2019) IMDb: Nailed it! https://www.imdb.com/title/tt6987788/ (katsottu 2.12.2019)
} 
ja jututtaa kameramiehiä, ja myös asiantuntijana toimiva leipuri riemuitsee räjähtäneen näköisistä kakuista. Ammattilaisinakin he näyttäytyvät rennossa roolissa ja palvelevat vernakulaarin trendin mukaista kakkumokailua samalla kun sarja itsessään on kaupallisesti tuotettu.

Kuvaston kierto jatkuu ohjelmasarjasta takaisin sosiaaliseen mediaan. Sekä nettilehdet että yksityiset julkaisijat esittelevät sarjan aineistoa kuvapareina. Esimerkiksi Donald Trumpin hahmoisen kakun malli ja toteutus ohjelmasarjan ensimmäisen kauden 6. jaksossa kiertää meeminä, ja Tumbrl-blogipalvelussa on julkaistu kuvia, joissa kakku-Trump on lisätty uutiskuviin presidentin paikalle. ${ }^{6}$

Kakkumokia koskevan kulttuurintuotannon siirtyminen mediasta toiseen on esimerkki hybridisyydestä, jossa ammattilaisten ja osallistuvan yleisön roolit pysyvät erillisinä vaikka kumpikin jäljittelee toistaan. Vernakulaarit toimijat ovat tässä ammattituotannolle vain aineiston ja valintoja tekevän yleisön roolissa. Tilanne on toinen, kun vernakulaari auktoriteetti haastaa institutionaalisia toimijoita.

\section{Vernakulaari auktoriteetti}

Vernakulaarilla auktoriteetilla tarkoitetaan toimijalla tai vernakulaarilla diskurssilla olevaa arvovaltaa ja uskottavuutta (Howard 2013; 2019). Se voi perustua vastakulttuuriseen asenteeseen ja erottautumiseen instituutioista, toisaalta taas tavallisuuteen ja perinteisyyteen. Perinteellä on tyypillisesti vernakulaaria auktoriteettia, koska ajattelutavan tai ilmaisun laaja tunnettuus tekee siitä legitiimin ja uskottavan sekä yhdistää sen käyttäjiksi tunnistautuvia ihmisiä. Yksilö voi hyödyntää vernakulaaria auktoriteettia tuottamalla ja toistamalla yhteisön legitimoimaa perinnettä oikealla tavalla. Samalla hän vetoaa valtaan, jota on perinnettä ylläpitäneillä sukupolvilla kollektiivisesti. Perinteiden jatkuvuudella ja yhdenmukaisuudella on todistusvoimaa silloinkin, kun ne ovat keksittyjä ja kuviteltuja. (Howard 2013, 73-74, 80.) Toistuminen on olennaista myös riippumatta siitä, tapahtuuko yhdenmukaisen toiminnan kasautuminen lyhyellä vai pitkällä aikavälillä. Internet tekee samansuuntaisen ilmauksen toistumisen erityisen tehokkaasti näkyväksi ja luo yksilöiden tekemien julkaisujen pohjalta nopeasti mielikuvan kollektiivisuudesta, joka edelleen lisää samansuuntaisia ilmaisuja. (Howard 2019, 76.) Digitaalisessa kulttuurissa pitkä ajallinen jatkumo ei edes ole hyve. Etenkin meemien kohdalla arvostus perustuu uudistumiseen ja oikeanlaisen aineiston hyödyntämiseen oikeaan aikaan. Vanhentuneiden ainesten käyttö on noloa ja osoittaa heikkoa asiantuntemusta.

Vernakulaarilla auktoriteetilla voidaan tarkoittaa paitsi ominaisuutta myös yksilöä, jolla on vertaisryhmän tai suuren yleisön tunnustamaa arvovaltaa ilman instituutioperustaa (esim. Räty 2019, 24-25). Sellaisia voivat olla yksinkertaisimmillaan yhteisön arvostamat perinteen tai arkisten toimien taitajat, kuten kätevät leipurit ja nikkarit, tai vernakulaarien käytäntöjen ja ilmaisukanavien taitajat, kuten hyvät kertojat tai digitaalisten kuvien muokkaajat. Vernakulaareja auktoriteetteja voivat olla myös vaikkapa fani-, uskonnollisten tai ideologisten ryhmien paikalliset johtohahmot. Toiminnassa voivat korostua eri tavoin vertaisuus ja instituutioiden ulkopuolisuus. Osa varsin erikoistuneistakin asiantuntijoista pysyy instituutioiden

6 Tumbrl:Trump cake. https://www.tumbral.com/tag/Trump\%20cake (katsottu 20.4.2020.) 
ulkopuolella aiheensa tai asenteensa vuoksi kuten kansanparantajat, itseoppineet ravitsemusgurut tai ufokulttuurin asiantuntijat.

Vernakulaariin auktoriteettiin liittyvät kiinteästi vernakulaarit verkostot, joissa merkityksenannot kuten samanmielisyyden osoitukset kasautuvat nopeasti ja jotka toimivat näin auktorisoivina rakenteina. Internet on tehnyt yksilöille aiempaa helpommaksi verkostoitua itse valittujen arvojen, toiminnan ja sisältöjen ympärille ilman instituutioiden välittävää roolia. Internet-pohjaisten vernakulaarien verkostojen voima on tullut näkyväksi esimerkiksi Lähi-idän poliittisissa protesteissa tai rokotuskriittisessä liikkeessä, joissa kasautunut samanmielisyys on vahvistanut yhteisiä näkemyksiä. Verkostoissa voi jakaa relevanttia tietoa ja vertaiskokemuksia, mutta toisaalta viestintä ja vaikutteet voivat jäädä niissä yksipuolisiksi. (Howard 2012, 42; 2013, 82-83; Räty 2019, 23-26.) Toisin sanoen syntyy samanmielisten kuplia. Niiden suhteet toisiinsa ja institutionaalisiin toimijoihin voivat muodostua jännitteisiksi etenkin, kun kyse on vallasta. Vernakulaari auktoriteetti on hybridistä, kun omaehtoinen tuotanto kaupallistuu tai kun kaupalliset tai poliittiset toimijat hyödyntävät vernakulaaria rekisteriä ja retoriikkaa.

\section{Populistinen retoriikka ja vernakulaari auktoriteetti}

Populismin voi määritellä vetoamiseksi poliittisesta päätöksenteosta syrjäytettyyn kansaan (Herkman 2019) tai tavallisten ihmisten pyrkimykseksi vastustaa elitististä hallintoa, joka kohtelee heitä huonosti (Albertazzi ja McDonnell 2008, 3-4). Populismilla ei ole vakiintuneita sisältöjä vaan se on retoris-performatiivinen ilmiö, jolle ovat ominaisia ristiriidat ja vastakkainasettelut (Palonen ja Saresma 2017). Sellaisena populismi rinnastuu vernakulaariin rekisteriin, jolla puhutellaan vertaisia ja korostetaan omaa erillisyyttä instituutioista. Perussuomalaisten puheenjohtajia voi tarkastella esimerkkinä vernakulaarin auktoriteetin hybridisyydestä. Timo Soini ja Jussi Halla-aho ovat panostaneet vernakulaarin auktoriteetin rakentamisessaan erilaisiin strategioihin.

Perussuomalaisten pitkäaikaisena puheenjohtajana toimiessaan Timo Soini rakensi kansanomaista imagoa tavallisena, rehellisenä, tyyliltään huolittelemattomana suomalaisena miehenä. Omaelämäkerrallisessa teoksessaan Maisterisjätkä (2008) hän luonnehti itseään kirjan nimen mukaisella hybridisellä käsitteellä, joka yhdistää toisiinsa akateemisen ihmisen ja tavallisen, kouluja käymättömän miehen. Soinin valitsema nimi puolueelle viittasi myös tavallisuuteen. (Kovala ja Pöysä 2018, 164-167.) Soinin vernakulaari auktoriteetti on perustunut yhteisyydestä nousevaan vertaisuuteen, vaikka myös eliitin vastustus oli keskeinen osa sitä. Puolueen nykyisen puheenjohtajan Jussi Halla-ahon habitus sen sijaan on lähempänä akateemista ja retoriikka korostetusti vastakulttuurista (Kovala ja Pöysä 2018, 170-171). Hänen vernakulaari auktoriteettinsa puhuttelee hajanaisempaa, digitaalisissa ympäristöissä toimivaa joukkoa.

Politiikassa vastakulttuurinen vernakulaari retoriikka hajottaa perinteistä poliittista diskurssia. Halla-ahon ja hänen seuraajiensa aktiivisuus sosiaalisessa mediassa (ks. Palonen 2017) siirtää valtaa perinteiseltä valtaeliitiltä vernakulaareille verkostoille. Digitaalisille ympäristöille tyypillisen vernakulaarin rekisterin kuten emojien käyttö rakentaa eroa institutionaaliseen toimijuuteen ja perinteisiin poliitikkoihin, jotka eivät välttämättä hallitse kyseistä rekisteriä. Tuore esimerkki on joulukuussa 2019 käyty keskustelu Halla-ahon emojien käytöstä 
- erityisesti hänen runsaasti viljelemästään popcorn-emojista, jota perinteisempään viestintään tottuneet eivät osanneet tulkita.

Emojit saivat alkunsa 1900-luvun lopulla vernakulaarina käytäntönä rakentaa näppäimistöjen merkeistä tunnetta ilmaisevia kasvoja eli hymiöitä tekstin tulkintaa ohjaamaan (ks. esim. Saarikoski ym. 2009, 218-219). Laitevalmistajat kehittivät niistä kuvia, joita löytyy matkapuhelinten tekstivalikoista. Kaupallinen emojien valikoima kasvaa jatkuvasti ja muokkaa vernakulaareja diskursseja, mutta emojien tulkinta on kulttuurisidonnaista. Kuvat toimivat metaforina, joiden merkitys voi perustua yhtä hyvin kaltaisuuteen kuin kontekstiin. Esimerkiksi ruoan ja vihannesten joukossa julkaistu munakoiso-emoji viittaa käytössä myös rankaisemiseen (=kumipamppu) tai ihmisen anatomiaan. Popcorn-emoji viittaa popcornin syömiseen elokuvissa ja tapahtumien seuraamiseen viihteenä niihin osallistumatta.

Poliittisen keskustelun kommentointi popcorn-emojin kera ilmaisee asettumista huvittuneen sivustakatsojan rooliin. Taustalla on vernakulaarista nettikulttuurista tuttu käytäntö provosoida muita (poliittisesti) ongelmallisilla väitteillä ja vetäytyä sitten seuraamaan kiihtyvää väittelyä. Tällainen trollaaminen (ks. esim. Phillips 2015) jakaa sosiaalista todellisuutta kahteen leiriin: internet-käyttäjien sisäpiiriin, joka ymmärtää provokaation viihteenä, ja niihin, joita vedätetään eli jotka tarttuvat kysymykseen tosissaan. Tämä kuvio tarjoaa vain vedätettävien roolin vallassa oleville ja viranomaisille, joiden on puututtava kuohuttaviin väitteisiin (Pullinen 2019). Esiintyminen vallankäyttäjistä poikkeavana ryhmänä ja pelaaminen eri säännöillä kuin perinteisessä politiikassa on vernakulaarin auktoriteetin rakentamista. Toimittaja Jussi Pullinen on kuvaillut tämän trollauksen kulttuuriksi nimittämänsä strategian vernakulaaria hybridisyyttä seuraavasti:

Trollauksen kulttuurista elävät puolueet esiintyvät mielellään ulkopuolisina. Jo perussuomalaisten luoja Timo Soini puhui mielellään "vanhoista puolueista", joita hän seurasi kuin sivullisena, vaikka teki politiikkaa siinä missä muutkin. Verkon logiikan vaistomaisesti tunteva Trump puolestaan twiittaa yhä säännöllisesti häntä vastaan olevasta järjestelmästä, vaikka on maailman vallakkain ihminen. (Pullinen 2019.)

Vallan keskiössä hyödynnetään vernakulaaria auktoriteettia rakentamalla mielikuvaa vertaisuudesta ja ilmaisemalla erillisyyttä valtarakenteista, vaikka samalla tosiasiassa käytetään institutionaalista valtaa. Hybridinen diskurssi on jatkuvaa ja hienovaraista oman aseman, sidosten ja sympatioiden linjaamista. Internetkeskusteluille ominaisen vernakulaarin rekisterin hallinta on yksi tapa vetää raja omien ja ulkopuolisten välille. Rekisterin hallinta luo myös vertaisuuden tunteita, mikä on somevaikuttamisen tärkeä ulottuvuus.

\section{Somevaikuttajat ja vernakulaarin auktoriteetin hybridisyys}

Somevaikuttajiksi tai influenssereiksi kutsutut digitaalisen kentän aktiiviset toimijat ovat tyypillisiä nykypäivän vernakulaareja auktoriteetteja. Somevaikuttaja on somepersoona tai -yhteisö, joka on kerännyt suuren ja sitoutuneen seuraajakunnan, jolloin hän tai se pystyy vaikuttamaan yleisönsä mielipiteisiin, asenteisiin ja useimmiten myös kulutuspäätöksiin. Nämä sosiaalisen median kautta tunnustetun asemansa saavuttaneet mielipidevaikuttajat ja roolimallit nauttivat arvostusta kanssakäyttäjiensä keskuudessa, koska he hallitsevat verkkoyhteisön jäseniin vetoavat, tietylle verkkokulttuurin osa-alueelle tyypilliset ilmaisutavat eli vernakulaarin rekisterin. Somevaikuttajat voivat olla esimerkiksi bloggaajia, vloggaajia (eli 
videobloggaajia), tubettajia (Youtube-palvelussa vloggaavia), instaajia (Instagramin käyttäjiä) tai näitä kaikkia yhtäaikaisesti. Nykyisin somevaikuttaminen on monikanavaista ja hybridisoitunutta, ja useat somevaikuttajat käyttävät Instagramia ainakin pääkanavansa tukena. (Esim. Hänninen 2018; Abidin 2016a, 1, 56, 387; Noppari ja Hautakangas 2012, 91-92.)

Suosituimpien somevaikuttajien vernakulaari auktoriteetti eli Howardin (2013; 2019) määrittelemä arvovallan ja uskottavuuden saavuttaminen on tulosta seuraajakunnan vakiintumisesta ja toiminnan ammattimaistumisesta. Somevaikuttajat edustavat hybridistä vernakulaaria (Howard 2008a; 2008b), sillä vaikka he asemoituvat instituutioista erillisiksi, he osallistuvat kaupalliseen toimintaan monellakin tasolla. Useat yritykset ja organisaatiot hyödyntävät somevaikuttajia omassa markkinoinnissaan, mikä näyttäytyy seuraajille kaupallisen yhteistyön muodossa. Yksinkertaisimmillaan tämä tarkoittaa sitä, että laatiessaan tiettyä tuotetta tai palvelua koskevan julkaisun somevaikuttaja saa korvauksen tuotteen valmistajalta tai palvelun tarjoajalta. (Noppari ja Hautakangas 2012, 137-138.) Somevaikuttajuus kulminoituu kuitenkin tietynlaiseen autenttisuuteen perustuvaan luotettavuuteen, mikä on markkinoinnin näkökulmasta uskottavampaa kuin yritysten oma sisältötuotanto verkkoympäristöissä (esim. Marwick 2013). Vaikuttajamarkkinoinnin näkökulmasta somevaikuttajat voidaan jakaa mega-, makro- ja mikrovaikuttajiin. Mikrovaikuttajat eivät tavoita laajoja massoja, vaan heidän seuraajajoukkonsa on kohdentuneempaa ja rajatumpaa. Tämä saattaa näyttäytyä tietylle kohderyhmälle aidompana kuin äärimmilleen kaupallistunut (mega) markkinointi ammattivaikuttajineen. (Reinikainen 2018.)

Varhaisimpia somevaikuttamisen muotoja on ollut lifestyle-bloggaaminen, jonka piiriin on luettu niin muoti-, kauneus- ja fitness- kuin ruoka-, terveys-, matka- ja äitiysbloggaaminenkin (esim. Noppari ja Hautakangas 2012, 19; Hänninen 2015, 54; Turtiainen 2017, 59). Nämä Suomessa vuoden 2005 paikkeilla yleistyneet, tiettyihin teemoihin keskittyviä sisältöjä ja itsensä esittämistä yhdistävät blogit juontavat juurensa varhaisista verkkopäiväkirjoista, mikä selittää osaltaan sisältöjen painottumisen omasta (arki)elämästä kertomiseen (Suominen ym. 2013, 73: Östman 2007, 52; Rettberg 2014a, 7; 2014b, 23). Hyvä esimerkki suomalaisesta,

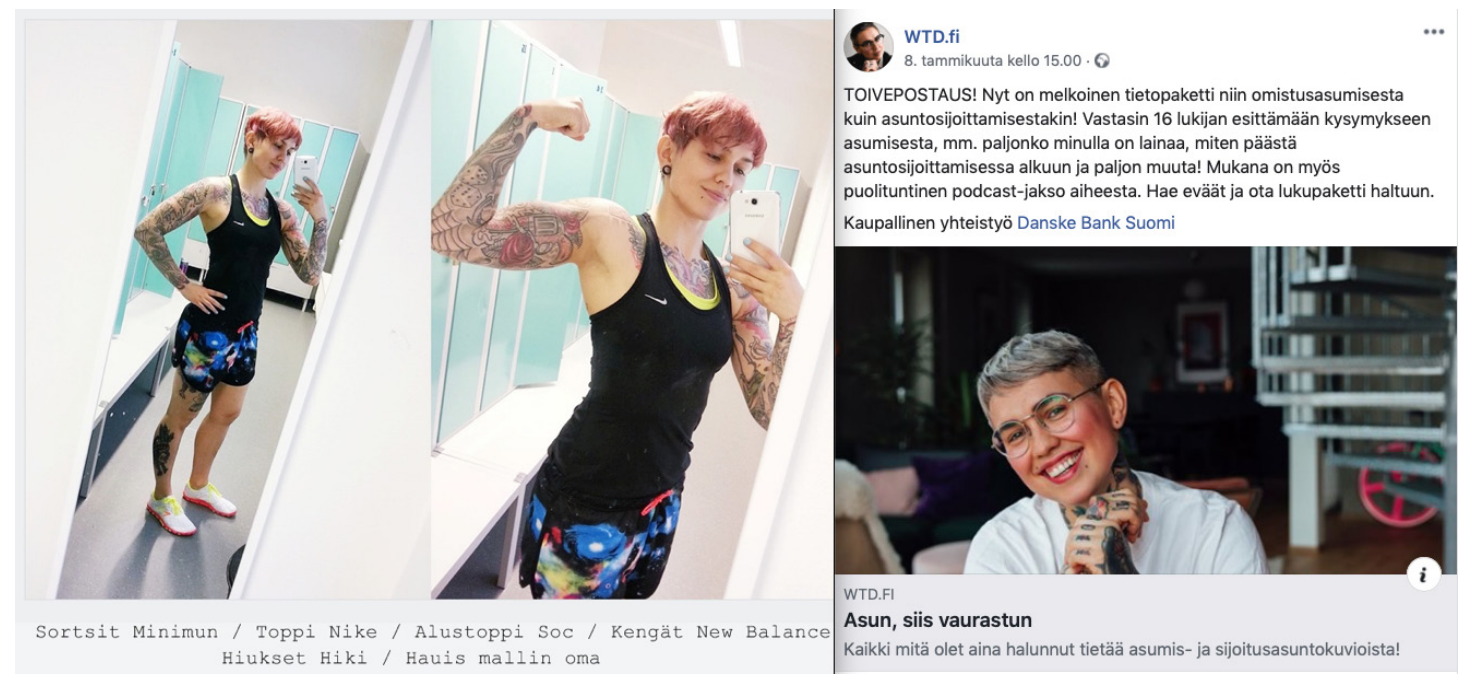

Kuva 3. Kuvakaappaukset Natan White Trash Disease -blogikuvituksesta 24.5.2013 (vasemmalla) ja hänen blogikirjoitusta mainostavasta Facebook-päivityksestään 8.1.2020 (oikealla). Kuva havainnollistaa, kuinka hänen päivitysten aihepiirit ja sitä myötä kaupallisen yhteistyön muodot ovat muuttuneet vuosien saatossa. 
lifestyle-bloggaamisella aloittaneesta somevaikuttajasta on White Trash Disease -bloginsa ${ }^{7}$ vuonna 2011 perustanut Natalia "Nata" Salmela. Hän on ponnistanut blogosfääristä sisällöntuotantokouluttajaksi, ruokakirjailijaksi ja Ylen Aamutelevision digitaalisen maailman asiantuntijaksi. Nata nimitti itseään vuonna 2013 muotibloggaajaksi, mutta hänen sosiaalisen median sisältönsä ovat vaihdelleet elämäntilanteen mukaan. Viime vuosina Nata on julkaissut eniten ruokaa ja ravintoloita sekä remontointia ja asuntosijoittamista - ja aivan viime aikoina raskauttaan ja sitä kautta äitiyttä ja vauvatarvikkeita - koskevia päivityksiä. Poikkeuksellisimpien yhteistyötahojen joukosta löytyvät hänen kohdallaan esimerkiksi Hyvinkään ja Hämeenlinnan kaupungit (Nyman 2019; Valkama 2018). Pelkkä bloggaaminen on hänen kohdallaan vaihtunut Instagramin ${ }^{8}$, Facebookin ${ }^{9}$, Twitterin ${ }^{10}$ ja podcastien ${ }^{11}$ myötä monikanavaiseen somevaikuttamiseen.

Natan kohdeyleisöä ovat 28-40-vuotiaat, mutta nuorempien sosiaalisen median käyttäjien keskuudessa vernakulaarin auktoriteetin asema on tyypillisempää saavuttaa vloggaamisen kautta. Natan tavoin uraa sosiaalisen median ulkopuolellakin on luonut tubettajana tunnettu, ensimmäisen proosateoksensa loppuvuodesta 2019 julkaissut Sita Salminen. Tubeconissa vuoden 2019 parhaan videon palkinnon uudessa ASMR-kategoriassa voittaneella Sitalla on kahdella YouTube-kanavallaan ${ }^{12}$ yhteensä yli 350000 tilaajaa (ASMR-videoista ks. Turtiainen
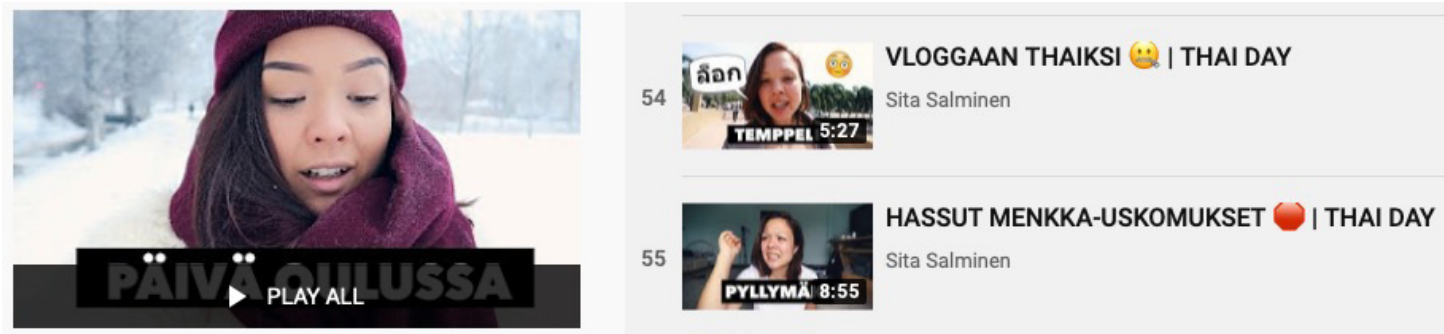

Sitan My day -videot (2016-2019)

92 videos $\cdot 25,906$ views $\cdot$ Last updated on Jan 29, 2020 $\equiv_{+} \quad y_{y} \rightarrow \cdots$

Tältä soittolistalta löydät mun vlogit kanavan alkuajoilta nykypäivään saakka. Näe mun entistä arkea Oulussa, muutto pääkaupunkiseudulle ja nykyistä elämää Helsingissä 6
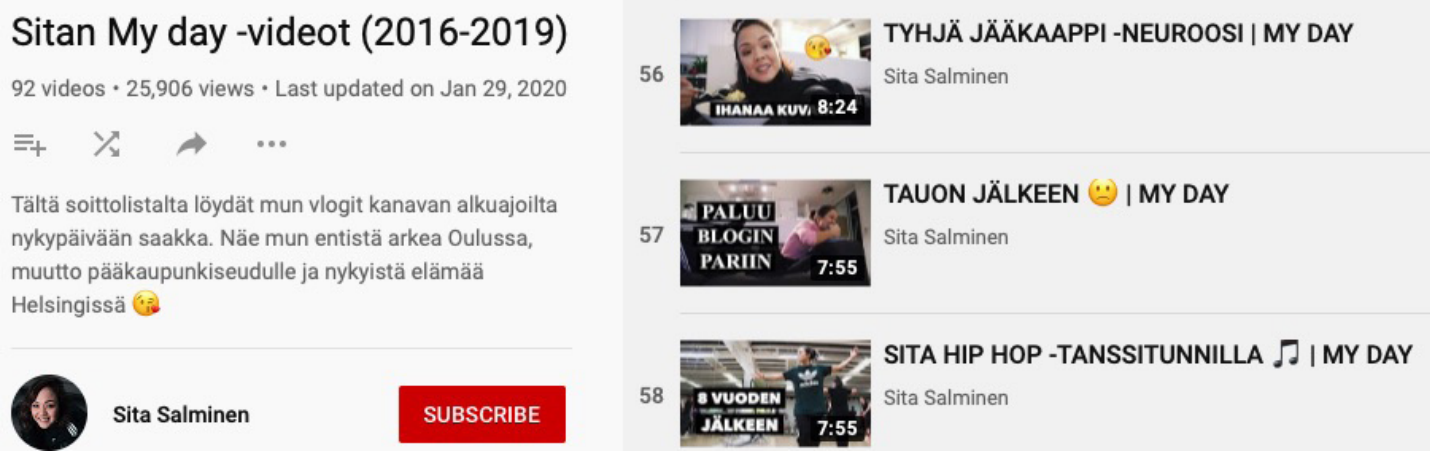

Kuva 4. Kuvakaappaus (6.2.2020) Sitan Youtube-kanavan My day -soittolistalta. Muutaman videoleikkeen otsikon perusteella saa jonkinlaisen käsityksen siitä, millaisten aihepiirien käsittelystä hänen some-vaikuttajuutensa muodostuu.

$7 \quad$ White Trash Disease -blogi, http://wtd.fi. Natalia Salmela (o.s. Tolmatsova) bloggasi ennen omaa WTD Media -yritystään ja Asennemedia-vaikuttajamarkkinointitoimiston verkostoa Indiedays-sivustolla (9/2011-5/2013) ja Trendi-lehden Lily-verkkoyhteisössä (5/2013-4/2016).

8 Instagram-tili natasalmela, Natalia Salmela, https://www.instagram.com/fitoona/https://www.instagram.com/ natasalmela/

9 Facebook-profiili Natalia Salmela, https://www.facebook.com/natalia.tolmatsova

10 Twitter-tili Natalia Salmela, @nataliasalmela, https://twitter.com/nataliasalmela

11 Ysistä viiteen -podcast, https://play.acast.com/s/ysistaviiteen; Holvi - podcast yrittäjyydestä, https://play.acast.com/s/ holvipodcast

12 YouTube-kanava Sita Salminen, https://www.youtube.com/user/sitruunamehukas; YouTube-kanava ASMR Sita Sofia https://www.youtube.com/channel/UCjNyeUaGpD0o7z5VbruS6-A 
2019). Natan tavoin Sitallakin on oma podcast ${ }^{13}$, blogi ${ }^{14}$, Facebook-profilili ${ }^{15}$, Instagram- ja Twitter-tilit ${ }^{16}$ sekä lisäksi nuorempien someseuraajien suosiossa oleva Snapchat-tili" ${ }^{17}$. Sita Salminen tienaa sata tonnia kertomalla elämästään ja rapistelemalla mikrofonin ääressä" -otsikoidussa Op.median haastattelussa Sita valottaa, miten Tube-ammattilaisuus koostuu kaupallisten yhteistöiden lisäksi live-esiintymisistä kuten puhujakeikoista ja Meet \& Greet -fanitapaamisista (Rajala 2019).

Nata ja Sita ovat hyvin tyypillisiä esimerkkejä tämän päivän vernakulaareista auktoriteeteista. He ovat omassa yhteisössään arvossa pidettyjä mielipidevaikuttajia ja roolimalleja, jotka ovat päätyneet asemaansa vertaisena toimimisen lähtökohdista. Heistä on tullut suosittuja oman persoonansa kautta - "tavallisesta" elämästään kertomalla. Heidän erityistaitonsa on ilmaista itseään kiinnostavasti sosiaalisen median kanavilla. Someammattilaisina he painivat megavaikuttajien luokassa ja ovat jo ohittaneet omaehtoisuuden ja ammatillisen toiminnan risteyskohdan. Kun omaehtoinen sisällöntuotanto kaupallistuu ja ammattimaistuu, auktoriteettiasema muuttaa muotoaan. Sosiaalisen median vertaisesta toimijasta julkisuuden henkilöksi (Natan ja Sitan kohdalla myös esimerkiksi kirjailijaksi) muuttuminen on askel institutionaalisemman auktoriteetin suuntaan. Sosiaalinen media on kuitenkin pulIollaan Natan ja Sitan kaltaisia elämäjulkaisijoita (ks. Östman 2015), jotka eivät tule koskaan saavuttamaan niin suurta suosiota, että heistä tulisi someammattilaisia - siitä huolimatta heillä voi olla tai ainakin he tavoittelevat vernakulaaria auktoriteettia eli vaikutusvaltaa seuraajiinsa YouTubessa ja muilla sosiaalisen median kanavilla. Haave elättää itsensä "omalla jutulla" on kuitenkin somevaikuttajien keskuudessa tavallinen.

\section{Somevaikuttajat ja vernakulaari rekisteri}

Omaehtoisen ja institutionaalisen välinen rajanveto on sosiaalisen median aikakaudella välillä hankalaa, minkä vuoksi auktoriteetin ja vertaisuuden välisiltä jännitteiltä ei voida välttyä. Kaupallisen yhteistyön ollessa kyseessä somevaikuttaja asettuu institutionaalisten toimijoiden ja vertaistensa välille vuorovaikuttaen molempiin suuntiin. Hänen on ylläpidettävä seuraajiensa kanssa faattista viestintää eli eräänlaista small talkia henkilökohtaisuuden tunnun takaamiseksi (Abidin 2016b, 3). Vernakulaarina auktoriteettina somevaikuttajan on säilytettävä uskottavuus yhteisönsä silmissä, mikä tarkoittaa tasapainoilua kaupallisten toimijoiden vaatimusten ja vertaisten odotusten välillä sekä jatkuvaa kulttuuristen normien uudelleenneuvottelua. Liiallinen tai liian ilmeinen yhteistyötahojen tuotteiden markkinointiin keskittyminen etäännyttää somevaikuttajaa omaehtoisuuden mielikuvasta. Tärkeää on vernakulaarin auktoriteetin kasvaessakin vertaisuuden tunteen ylläpitäminen, mikä onnistuu operoimalla ilmaisutyyliltään vernakulaarin rekisterin tasolla. Seuraajat eivät epäröi hylätä vernakulaaria auktoriteettia tai tuoda kantaansa ilmi, jos somevaikuttajan toiminta ja ilmaisutapa eivät (enää) miellytä. (Esim. Hänninen 2018; 2015, 62, 64; Noppari ja Hautakangas 2012, 62, 145.) Lifestyle-bloggaajien kohdalla negatiivisten kommenttien on todettu vaikuttavan niin julkaisujen sisältöön kuin tyyliinkin erityisesti silloin, kun kritiikki kääntyy loukkaavaksi tai suoranaiseksi häirinnäksi. Tällöin bloggaajat voivat alkaa vältellä

\footnotetext{
13 POKS-podcast, https://podtail.com/fi/podcast/poks/

14 Sita Salminen -blogi, https://sitasalminen.fi

15 Facebook-profiili Sita Salminen, https://www.facebook.com/sita.salminen/

16 Instagram-tili sitasalminen, ASMR Sita Sofia, https://www.instagram.com/sitasalminen/; Twitter-tili Sita Salminen, @ SitaSalminen, https://twitter.com/sitasalminen

17 Snapchat-tili Sita Salminen, https://www.snapchat.com/add/sitasalminen
} 
henkilökohtaisempien asioiden kertomista ja provokatiivisten aiheiden käsittelyä - mikä taas voi lisätä keinotekoisuuden ja näennäisen vernakulaarin tuntua ja sitä kautta jälleen tyytymättömyyttä seuraajien keskuudessa. (Hänninen 2018.)

Toisenlaisia jännitteitä saattaa syntyä silloin, kun vernakulaarin auktoriteetin näkemykset eivät kohtaa institutionaalisten toimijoiden kanssa. Oman elämänsä erittelystä julkaisujensa sisältöjä ammentavat somevaikuttajat esiintyvät usein kokemusasiantuntijan roolissa. Perehtynyt harrastuneisuus voi toisinaan pätevöittää toimimaan asiantuntija-asemassa, mutta joillain aloilla omaehtoisuuden painottamisessa piilee myös vaaransa. Viime vuosina keskustelua on herättänyt erityisesti hyvinvointialaan kytkeytyvien vernakulaarien auktoriteettien asema kyseisen kentän toimijoina. Omakohtaisiin kokemuksiin perustuvia ruokavalio- ja liikuntavinkkejä julkaisevien fitness- ja treenibloggaajien välittämä tieto on toisinaan jyrkästi ristiriidassa tieteelliseen tutkimukseen perustuvien ravitsemus- ja liikuntasuositusten kanssa. (Turtiainen 2017; ks. myös Huovila ja Saikkonen 2016.) Tällöin somevaikuttaja asettuu selkeästi ilmaisemaan erillisyyttä instituutioista ja identifioituu vastakulttuuriseksi alisteisen vernakulaarin edustajaksi.

Esimerkki ammatillisesti pätevästä hyvinvointialan asiantuntijasta on fitnessmallista ja-kisaajasta (esim. Iltalehti 15.6.2012; 8.1.2013) bloggaamisen kautta yhdeksi alan keskeisimmistä kotimaisista somevaikuttajista noussut Oona Tolppanen. Oonalla on koulutuksensa kautta auktorisoitu asema alalla, mutta hänen suosionsa perustuu vernakulaarin auktoriteetin systemaattiseen kasvattamiseen sosiaalisessa mediassa. Fitoona.com-blogisivustonsa ${ }^{18}$ lisäksi hän on aktiivinen erityisesti Instagramissa ${ }^{19}$. Oonalla on käytössään myös Facebook ${ }^{20}$ ja
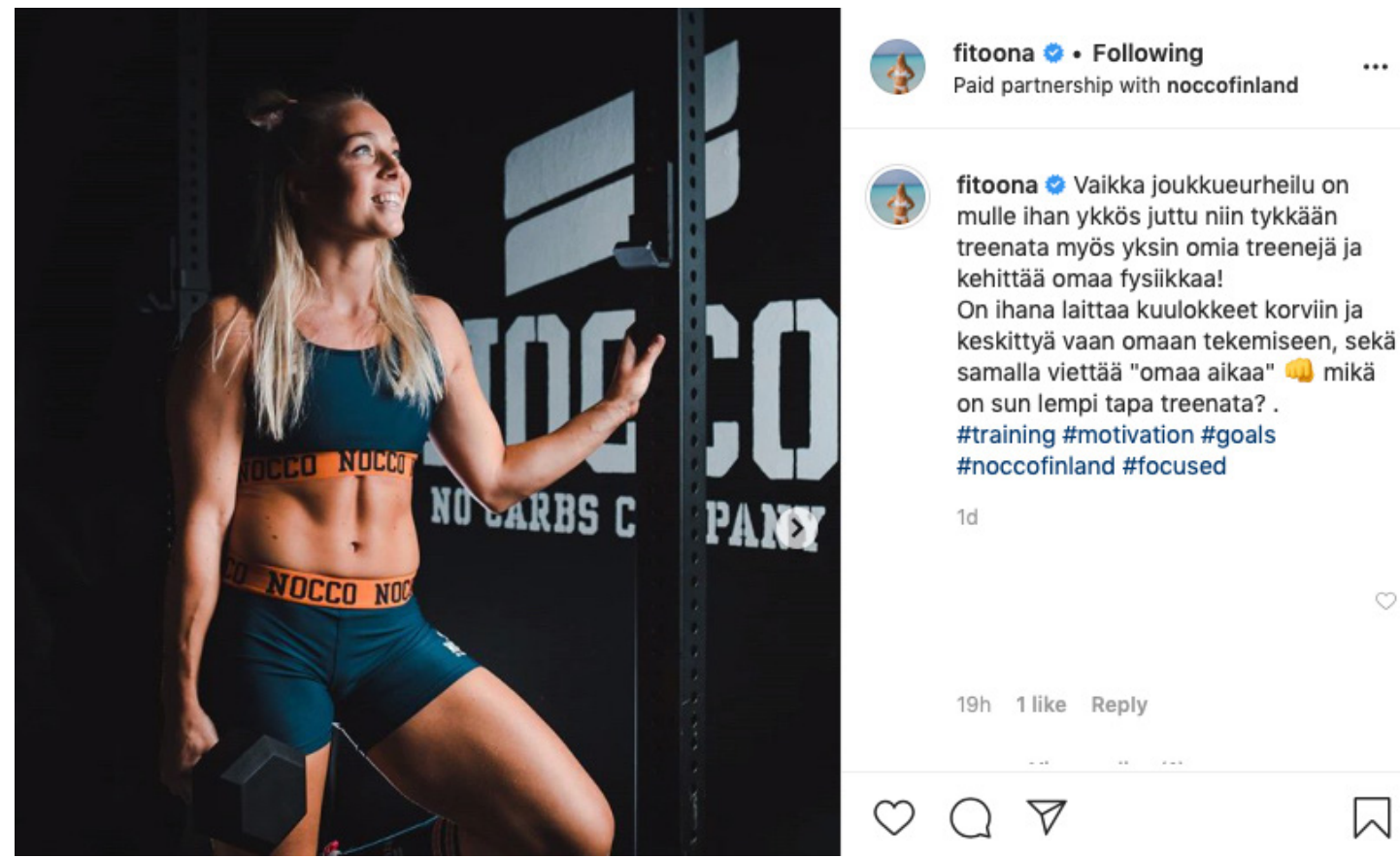

Kuva 5. Kuvakaappaus Oonan tuottamasta some-sisällöstä, jossa hän puhuttelee seuraajiaan ja tuo samalla esiin keskeisen sponsorinsa tuotteineen henkilökohtaisen Instagram-päivityksen muodossa (5.2.2020, seuraajien kommentit poistettu).

\footnotetext{
18 Fitoona.com-blogisivusto, https://www.fitoona.com

19 Instagram-tili fitoona, $\mathrm{COACH}$ - Oona Tolppanen, https://www.instagram.com/fitoona/

20 Facebook-profiili Oona Tolppanen, https://www.facebook.com/tolppanenoona/
} 
Twitter-tilit ${ }^{21}$ sekä YouTube-kanava ${ }^{22}$ ja hän tekee Urheilun äärellä -podcastiaa ${ }^{23}$. Liikunta-alan yrittäjänä ja valmentajana sekä puhujana ja kouluttajana toimivalla, viime vuosina tv-ohjelman gladiaattorinakin tutuksi tulleella Oonalla on itsellään monipuolinen urheilutausta. IIman sosiaalisessa mediassa toimivan yhteisönsä arvostusta ja vertaistensa tukea hänen uransa olisi voinut kuitenkin muotoutua hyvin erilaiseksi. Hän nimittää hyvinvointialan bloggaamistaan intohimoiseksi harrastuksekseen, vaikka yhteistyöjulkaisut tuovat hänelle varmasti myös huomattavia tuloja (ks. https://www.fitoona.com). Oonankin kohdalla vernakulaari ja institutionaalinen auktoriteetti ovat sosiaaliselle medialle tyypilliseen tapaan siis alkaneet sekoittua. Hänellä on kokemustietonsa ohella vahva ammatillinen osaaminen omalta alaltaan, mikä välittyy asiantuntevina sisältöinä, mutta samalla hän raottaa henkilökohtaista elämäänsä sen verran, että seuraajien on mahdollista samastua arkielämän tilanteisiin vertaisen tasolla. Someajan vernakulaarina auktoriteettina toimiminen onkin jatkuvaa tasapainoilua strategisuuden ja autenttisuuden välimaastossa. (Noppari ja Hautakangas 2012, 60-62; ks. myös Turtiainen 2016, 129.) Oona Tolppasen asema vernakulaarina auktoriteettina perustuu siihen, että hän hallitsee sosiaalisen median välineiden lainalaisuudet ja itsensä esittämisen käytännöt, minkä lisäksi hän huomioi seuraajansa omaehtoisessa sisältötuotannossaan taitavasti. Instagramille ominainen vernakulaarisuus (ks. Keller 2019) sopii parhaiten hänen tarkoituksiinsa ja otollisimman yleisön tavoittamiseen.

Läheskään kaikilta fitnessbloggaajilta ei kuitenkaan löydy sertifioitua alan koulutusta, vaan he ovat nousseet asiantuntija-asemaansa ainoastaan tuottamalla fitnesstietousdiskurssin eli hyvinvointiin ja ideaalikehoon kiinnittyvien artikulaatioiden - mukaista somesisältöä ja toimimalla itse tietynlaista elämäntapaa noudattavina roolimalleina. Raportoimalla omasta treenaamisestaan ja syömisestään he asettuvat seuraajiinsa nähden samanaikaisesti sekä vertaisen että esikuvan asemaan. (Turtiainen 2017.) He saavat yhteisössään hyväksyntää tuottamalla ja toistamalla fitnesskulttuurin legitimoimaa perinnettä oikealla tavalla, minkä voi nähdä tämän verkkoyhteisön kontekstissa paikallisena vernakulaarisuutena. Nämä somevaikuttajat voivat esittää niin varteenotettavaa kokemustietoa kuin heikommin perusteltavissa olevia mielipiteitäänkin vernakulaariin auktoriteettiin perustuvasta asiantuntija-asemastaan käsin. Kun kysymyksessä on ihmisten terveys, on somevaikuttajien harjoittamassa vallitsevan tiedon haastamisessa omat kauaskantoisetkin riskinsä. Asianmukaisen tiedon suodattaminen vaatiikin somevaikuttajien seuraajilta lähdekriittistä lähestymistapaa ja hyvää sosiaalisen median lukutaitoa, jotta he osaavat seuloa käyttöönsä omaan tilanteeseensa sopivia, luotettavia sisältöjä. Somevaikuttajat hallitsevat verkkoympäristön kulttuuriset käytännöt ja saattavat kiinnittää seuraajiensa huomion ensisijaisesti vakuuttavan oloisella ja räväkälläkin someajan itseilmaisulla faktojen oikeellisuuden sijaan - toisin sanottuna he hallitsevat vernakulaarille rekisterille ominaisen retoriikan. (Turtiainen 2017.)

Tutkijoiden mukaan sosiaalinen media on uusintanut vernakulaarin visuaalisuuden käsitettä. Erityisesti mobiilit palvelut, kuten Instagram, nähdään oman muotokielensä määrittävinä vernakulaareina alustoina, joilla on sekä palvelukohtaisia että sosiaalisen median sisältötuotannossa laajemmin jaettuja piirteitä. Instagramin affordansseihin kuuluvat kuvien jakamisen lisäksi merkintöjen (tags) ja filttereiden lisääminen kuviin. Teknologisten tarjoumien lisäksi tietyn sosiaalisen median alustan vernakulaarisuutta määrittävät sen käyttäjien

\footnotetext{
$21 \quad$ Twitter-tili Oona Tolppanen, @FITOONA, https://twitter.com/fitoona

22 YouTube-kanava Oona Tolppanen, https://www.youtube.com/channel/UCSXOP45qEiOCai9GxjIEEbw

23 Oona Tolppanen: Urheilun äärellä -podcast, https://www.supla.fi/ohjelmat/urheilun-aarella
} 
omaksumat kulttuuriset ja sosiaaliset käytännöt. Digitalisoituminen on arkipäiväistänyt muun muassa valokuvausta muuttaen sen kohteita ja tehden arjen estetiikasta jaetun kokemuksen. Määrittävin vernakulaari ominaispiirre 2000-luvun valokuvauksessa on selfie-kulttuurin keskeisyys ${ }^{24}$. (Keller 2019; Vainikka ym. 2017; Bucher ja Helmond, 2017; Tifentale ja Manovich 2015; Gibs ym. 2015; Murray 2013.)

Singaporelaista verkkokulttuuria tutkineen Crystal Abidinin mukaan selfiet (eli jaettaviksi tarkoitetut digitaaliset omakuvat, ks. esim. Senft ym. 2015; Marwick 2015) ovat keskeisessä roolissa nimenomaan somevaikuttajien toiminnassa. Keinotekoiseen autenttisuuteen perustuvat somevaikuttajien sisällöntuotantokäytännöt edustavat elämäntapaestetiikkaa, jota määrittää hänen mukaansa vallankumouksellinen joutavuus. Tällä Abidin tarkoittaa sitä, että selfieiden vaikutusvalta perustuu nimenomaan niiden ajateltuun vähäpätöisyyteen ja epäluovuuteen. (Abidin 2016b.) Somevaikuttajien selfieiden voikin nähdä kaikessa yleisyydessään ja tavallisuudessaan edustavan vernakulaaria juuri Howardin (2008a) määrittelemällä tavalla - valtadiskurssin vastaisina yleisen mielipiteen muokkaajina. Julkisessa keskustelussa selfieitä on pidetty turhamaisena ja narsistisena sukupolvi-ilmiönä, mutta selfieiden tutkijat ovat paikantaneet niiden potentiaalin muun muassa kehosuhdetta muokkaavina käytäntöinä (esim. Hynnä 2018). Kuvamuokkauksen palvelussa mahdollistavat filtterit voi esimerkiksi nähdä turhamaisuuden sijaan itsensä etäännyttämisen välineenä (ks. esim. Rettenberg 2014, 26-27), jolloin niiden käyttö on samalla välineelle tyypillisen muotokielen haltuunottamista. Vernakulaarien genrejen, kuten selfien, sekä muiden digitaalisten ilmaisutapojen ja -alustojen taitava käyttö eli vernakulaarin rekisterin hallitseminen tarjoaa somevaikuttajille väylän nimenomaan vastakulttuuriseen valtaanpääsyyn.

Somevaikuttajilla ja heidän seuraajillaan on paljon valtaa suhteessa institutionaalisempiin vallankäyttäjiin, kun puhutaan verkkokulttuurien muotoutumisesta. Palveluntarjoajat muokkaavat sovellustensa ominaisuuksia sosiaalisen median käyttäjien omaksumien tapojen ja mieltymysten mukaan, ja tässä somevaikuttajat toimivat usein suunnannäyttäjinä. Instagram kopioi vain tietyn ajanjakson näkyvissä olevat julkaisut mahdollistavan tarinatoiminnon (stories) Snapchatilta huomattuaan suosittujen instagrammaajien siirtyneen tuottamaan osan monikanavaisesta sisällöstään toiseen palveluun. Somevaikuttajat ovatkin alkaneet tuottaa katoavia ja striimattuja sisältöjä arkistomaisten, puolipysyvien julkaisujen sijaan tai vähintäänkin niiden rinnalle ${ }^{25}$. Samalla siloitellut, huippulaatuiset kuvat ovat vaihtuneet spontaanimpaan raakamateriaalin eli huolittelemattomamman ja samalla autenttisemman vaikutelman luovan, amatöörimäisemmän estetiikan suosimiseen. Seuraajilta tämä vaatii jatkuvampaa huomion kiinnittämistä somevaikuttajiin sen pelossa, ettei mikään katoavaksi tarkoitettu sisältö vain mene heiltä ohi. Laskelmoidun amatöörimäisyyden myötä filtterein täydellisyyteen pyrkineet Instagram-vaikuttajat ovatkin joutuneet vähitellen väistymään rosoisemman ja välittömämmän eli vernakulaarimman ilmaisun tieltä. (Abidin 2018, 88-93.)

\section{Lopuksi: Vernakulaari vertaisuutta ilmaisevana rekisterinä}

Digitaalisissa ympäristöissä näkyy yhä selvemmin, ettei vernakulaari ole pelkästään institutionaalisen vallan puuttumista tai sille alistumista vaan toisenlainen vallan ja uskottavuuden

24 Muita valokuvauksen normeja muuttaneita vernakulaareja genrejä on esim. "photobombing" eli odottamaton ilmestyminen kuvaan, jota ollaan ottamassa jostain toisesta kohteesta, ks. Ibrahim 2019.

25 Tässä artikkelissa käsitelty somevaikuttaja Oona Tolppanen julkaisi elokuun 2019 aikana vain 35 pysyvää Instagram-julkaisua ja lähes 200 katoavaksi tarkoitettua Instagram-tarinaa. 
muoto, jota kaupalliset ja poliittisetkin toimijat tavoittelevat. Sosiaalisen median hybridisten käytäntöjen ja sisältöjen myötä vernakulaarin ja institutionaalisen välinen suhde on neuvoteltu osittain uudelleen: kumpikin hyödyntää toistaan, ja hybridisyys muodostuu nopeasti monikerroksiseksi kuten esimerkissä kakkumokista. Sosiaalinen media on muuttanut vernakulaaria auktoriteettia entistä omaehtoisempaan ja jopa itsekeskeisempään suuntaan, koska somevaikuttajien kohdalla kaikki perustuu ennen kaikkea itsen esittämiseen. Samalla omaehtoisen sisältötuotannon takaa löytyy kaupallisten tahojen vaikuttimia, ja vernakulaarit ja kaupalliset intressit sekoittuvat (Howard 2008b, 192-194). Hybridisyys lisää somevaikuttajienkin vernakulaaria auktoriteettia, kunhan kaupalliset intressit pysyvät taka-alalla ja palvelevat omaehtoisia tavoitteita.

Robert Glenn Howardin näkemykset digitaalisen vernakulaarin hybridisyydestä ovat olleet tämän artikkelin tärkeänä inspiraationa. Niillä on erityinen relevanssi folkloristiikassa, jossa edelleen puretaan vanhoja mutta sitkeitä oletuksia valtakulttuurin vaikutuksen ulottumattomissa olevasta "puhtaasta" kansankulttuurista. Howardin teksteissä korostuu, hybridisyyden osanakin, erillisyys instituutioista vernakulaarin keskeisenä ja auktoriteettia lisäävänä ominaisuutena (esim. Howard 2013, 81). Me olemme lähestyneet vernakulaariin rekisteriin sisältyvää itsen asemointia kahdelta kannalta: rekisterin valinta ilmaisee samanaikaisesti yhteyttä yhteen ryhmään ja eroa johonkin toiseen. Esimerkiksi Halla-ahon popcorn-emojien käyttö luo yhteisyyttä niiden "valveutuneiden" kesken, jotka ymmärtävät viestin, samalla kun sulkee pois niitä inmisiä, jotka eivät ymmärrä tätä nettikulttuurin rekisteriä. Somevaikuttajat puolestaan pitävät yllä vernakulaaria auktoriteettiaan ennen kaikkea yhteisyyttä luovin strategioin. Sellaisia ovat esimerkiksi henkilökohtaisuuden tuntua luova small talk, huolittelematon ja amatöörimäinen visuaalinen estetiikka sekä eri kanaviin sopivien tyylilajien oikea käyttö.

Vernakulaarin käsitteellistäminen rekisteriksi korostaa asemoitumisen tilannesidonnaista valinnaisuutta. Vertaisuus puolestaan kattaa ja päivittää digitaalisiin ympäristöihin aiemmat vernakulaariin liitetyt ulottuvuudet: yleisen ja alisteisen vernakulaarin sekä paikallisuuden. Paikallisuus ei digitaalisissa ympäristöissä enää perustu maantieteeseen vaan itse valikoitujen verkostojen omiksi ja tutuiksi koettuihin käytäntöihin ja sidoksiin. Yleisyys puolestaan on hajonnut lukemattomiksi alakulttuureiksi ja verkostoiksi, eikä koko "kansan" läpäisevää tavallisuutta välttämättä edes enää ole. Vertaisuus voi perustua omassa ryhmässä tai verkossa koettuun samankaltaisuuteen. Se voi perustua myös jaettuun vastakulttuuriseen kokemukseen, jolloin määräävänä strategiana on erillisyyden korostaminen. Vernakulaari rekisteri on varteenotettava näkökulma, kun tarkastellaan nyky-yhteiskunnan ja digitaalisten ympäristöjen sekoittuneita toimijuuksia. 


\section{Kirjallisuus}

Abidin, Crystal. 2016a. Please Subscribe!: Influencers, Social Media, and the Commodification of Everyday Life. Doctoral dissertation. Perth, University of Western Australia.

Abidin, Crystal. 2016b. "'Aren't these just young, rich women doing vain things online?': Influencer Selfies as Subversive Frivolity." Social Media+ Society 2(2).

Abidin, Crystal. 2018. Internet Celebrity: Understanding Fame Online. Bingley: Emerald Publishing Limited.

Agha, Asif. 2011. "Commodity Registers." Journal of Linguistic Anthropology 21(1): 22-53. https://doi.org/10.1111/j.1548-1395.2011.01081.x

Albertazzi, Daniele ja Duncan McDonnell. 2008. Introduction: The Sceptre and the Spectre. Teoksessa Twenty-First Century Populism: The Spectre of Western European Democracy, toimittaneet Daniele Albertazzi ja Duncan McDonnell, 1-11. London: Palgrave MacMillan.

Bauman, Zygmunt. 1992. Intimations of Postmodernity. London and New York: Routledge.

Bauman, Zygmunt. 2002. Notkea moderni. Tampere: Vastapaino.

Bendix, Regina. 1997. In Search of Authenticity. The Formation of Folklore Studies. Madison: The University of Wisconsin Press.

Benkler, Yochai. 2006. The Wealth of Networks: How Social Production Transforms Markets and Freedom. New Haven and London: Yale University Press.

Bronner, Simon. 1992. "Introduction." Teoksessa Creativity and Tradition in Folklore: New Directions, toimittanut Simon Bronner, 1-40. Logan: Utah State University Press.

Bruns, Axel. 2010. “From Reader to Writer: Citizen Journalism as News Produsage.”Teoksessa International Handbook of Internet Research, toimittaneet Jeremy Hunsinger, Lisbeth Klastrup ja Matthew Allen. Dordrecht, Heidelberg, London, New York: Springer.

Bucher, Taina ja Anne Helmond. 2017. "The affordances of social media platforms." Teoksessa The SAGE handbook of social media, toimittaneet Jean Burgess, Alice Marwick ja Thomas Poell, 223-253. London: Sage.

Cross, Mary. 2011. Bloggerati, Twitterati: How Blogs and Twitter Are Transforming Popular Culture. Santa Barbara: Praeger.

Delwiche, Aaron ja Jennifer Jacobs Henderson. 2013. "Introduction: What is Participatory Culture?" Teoksessa The Participatory Cultures Handbook, toimittaneet Aaron Delwiche ja Jennifer Jacobs Henderson, 3-9. New York: Routledge.

Fagerjord, Anders. 2010. "After Convergence: YouTube and Remix Culture." Teoksessa International Handbook of Internet Research, toimittaneet Jeremy Hunsinger, Lisbeth Klastrup ja Matthew Allen, 187-200. Dordrecht, Heidelberg, London, New York: Springer.

Gibbs, Martin, James Meese, Michael Arnold, Bjorn Nansen ja Marcus Carter. 2015. "\# Funeral and Instagram: Death, Social Media, and Platform Vernacular." Information, Communication \& Society 18(3): 255-268.

Haapalainen, Anna, Kaarina Koski ja Teemu Mantsinen. 2015. "Kieli ja kommunikaatio." Teoksessa Askel kulttuurien tutkimukseen, toimittanut Jaana Kouri, 205-220. Turku: Turun yliopisto.

Halliday, M. A. K. 1979. Language as Social Semiotic. The Social Interpretation of Language and Meaning. London: Edward Arnold. 
Heimo, Anne ja Kaarina Koski. 2014. "Internet Memes as Statements and Entertainment." FF Network 44: 4-12.

Heimo, Anne. 2013."Meemi tulee: Folkloristi, oletko valmis?"Elore 20(2): 54-65. http://www. elore.fi/arkisto/2 13/heimo.pdf

Herkman, Juha. 2019. Populismin aika. Tampere: Vastapaino.

Howard, Robert Glenn. 2008a. "The Vernacular Web of Participatory Media." Critical Studies in Media Communication 25(5): 490-513.

Howard, Robert Glenn. 2008b. "Electronic Hybridity: The Persistent Processes of the Vernacular Web." Journal of American Folklore 121(480): 192-218.

Howard, Robert Glenn. 2012. "How Counterculture Helped Put the 'Vernacular' in Vernacular Webs". Teoksessa Folk Culture in the Digital Age: The Emergent Dynamics of Human Interaction, toimittanut Trevor Blank, 25-45. Logan: Utah State University Press.

Howard, Robert Glenn. 2013. "Vernacular Authority: Critically Engaging 'Tradition"' Teoksessa Tradition in the Twenty-First Century: Locating the Role of the Past in the Present, toimittaneet Trevor Blank ja Robert Glenn Howard, 72-99. Logan: Utah State University Press.

Howard, Robert Glenn. 2019. "Vernacular Authority Speaks for the Glock: Heterogeneous Volition in an Institutional Proverb."Teoksessa Folkloristics in the Digital Age, toimittaneet Pekka Hakamies ja Anne Heimo, 73-91. Helsinki: Academia Scientiarum Fennica.

Huovila, Janne ja Sampsa Saikkonen. 2016. "Establishing Credibility, Constructing Understanding: The Epistemic Struggle Over Healthy Eating in the Finnish Dietetic Blogosphere." Health 20(4): 383-400.

Hynnä, Kaisu. 2018. "\#Lupanäkyä - kehopositiiviset selfiet affektiivisena käytäntönä." Lähikuva 31(3): 65-72.

Hänninen, Riitta. 2015. "Is this an advertisement or a personal account?'-Commercialisation of Lifestyle Blogs in Finland." Ethnologia Fennica 42: 54-69.

Hänninen, Riitta. 2018. "On the Dark Side of Lifestyle Blogging: The Case of Negative Anonyms." WiderScreen 11(3).

Ibrahim, Yasmin. 2019. "The Vernacular of Photobombing: The Aesthetics of Transgression." Convergence 25(5-6): 1111-1122.

Iltalehti 15.6.2012. Huh, mitä kaunottaria! Syyskuussa valitaan uusi fitness-malli. Äänestä oma suosikkisi jo nyt! https://www.lltalehti.fi/viihde/a/2012061515707481

Iltalehti 8.1.2013. Uskomaton muutos vuodessa - huh, mikä pala! https://www.iltalehti.fi/ iltvurheilu/a/20130108018060639

Ingraham, Chris. 2013. “Talking (About) the Elite and Mass:Vernacular Rhetoric and Discursive Status." Philosophy \& Rhetoric 46(1): 1-21.

Jenkins, Henry. 2006. Convergence Culture: Where Old and New Media Collide. New York and London: New York University Press.

Kallio, Kati, Tuomas M.S. Lehtonen, Senni Timonen, Irma-Riitta Järvinen ja Ilkka Leskelä. 2017. Laulut ja kirjoitukset: Suullinen ja kirjallinen kulttuuri uuden ajan alun Suomessa. Helsinki: Suomalaisen Kirjallisuuden Seura.

Kangaspunta, Seppo. 2011. "Traditionaalista yhteisöstä verkkoyhteisyyteen." Teoksessa Yksilöllinen yhteisöllisyys: avaimia yhteisöllisyyden ymmärtämiseen. Toimittanut Seppo Kangaspunta, 15-34. Tampere: Tampere University Press. 
Keller, Jessalynn. 2019. "'Oh, She's a Tumblr Feminist': Exploring the Platform Vernacular of Girls' Social Media Feminisms." Social Media+ Society 5(3).

Knobel, Michele ja Colin Lanshear. 2007. "Online Memes, Affinities and Cultural Production." Teoksessa A New Literacies Sampler, toimittaneet Michele Knobel ja Colin Lankshear, 199-228. New York: Peter Lang Publishing.

Knuuttila, Seppo. 1992. Kansanhuumorin mieli. Kaskut maailmankuvan aineksena. Helsinki: Suomalaisen Kirjallisuuden Seura.

Koski, Kaarina. 2011. "Mediakulttuurin muutos, YouTube ja folklore" Elore 18(1): 14-27. https://doi.org/10.30666/elore.78918

Koski, Kaarina. 2016. "The Legend Genre and Narrative Registers". Teoksessa Genre - Text Interpretation. Multidisciplinary Perspectives on Folklore and Beyond, toimittaneet Kaarina Koski, Frog ja Ulla Savolainen, 113-136. Helsinki: Finnish Literature Society.

Kovala, Urpo ja Jyrki Pöysä. 2018. The 'Jytky' of the Finns Party: Or, How to Take Advantage of Masculinity in Populist Politics. Teoksessa Populism on the Loose, toimittaneet Urpo Kovala, Emilia Palonen, Maria Ruotsalainen ja Tuija Saresma, 161-175. Jyväskylä: Jyväskylän yliopisto.

Krawczyk-Wasilewska, Violetta. 2016. Folklore in the Digital Age: Collected Essays. Kraków: Jagiellonian University Press.

Marwick, Alice. 2013. "'They're really profound women, they're entrepreneurs': Conceptions of Authenticity in Fashion Blogging." 7th international Alll conference on weblogs and social media (ICWSM).

Marwick, Alice. 2015. "Instafame: Luxury Selfies in the Attention Economy." Public Culture 27(1 75): 137-60.

McLaughlin, Thomas. 1996. Street Smarts and Critical Theory. Listening to the Vernacular. Madison: University of Wisconsin Press.

Morreall, John. 1983. Taking Laughter Seriously. Albany: State university of New York Press.

Murray, Susan. 2013. "New Media and Vernacular Photography: Revisiting Flickr." Teoksessa The Photographic Image in Digital Culture, toimittanut Martin Lister, 179-196. New York: Routledge.

Noppari, Elina ja Mikko Hautakangas. 2012. Kovaa työtä olla minä: muotibloggaajat mediamarkkinoilla. Tampere: Tampere University Press.

Noyes, Dorothy. 2012. "The Social Base of Folklore." Teoksessa Companion to Folklore, toimittaneet Regina Bendix ja Galit Hasan-Rokem, 13-30. Chichester: John Wiley \& Sons.

Nyman, Jael. 2019. Bloggaaja Natalia Salmela palkattiin asumaan kuukaudeksi Hyvinkäälle Kaupunki antaa käyttöön 90 neliön asunnon. Helsingin Sanomat 8.5.2019. https://www. hs.fi/kaupunki/hyvinkaa/art-2000006097378.html

Ono, Kent ja John Sloop. 2002. Shifting Borders: Rhetoric, Immigration, and California's Proposition 187. Philadelphia: Temple University Press.

Palonen, Emilia. 2017. "Perussuomalaiset ja ulkopuolisuuden paradoksi." Teoksessa Jätkät ja jytkyt: Perussuomalaiset ja populismin retoriikka. Toimittaneet Emilia Palonen ja Tuija Saresma. Tampere: Vastapaino 2017.

Palonen, Emilia ja Tuija Saresma. 2017. Perussuomalaiset ja populistinen retoriikka. Teoksessa Jätkät ja jytkyt: Perussuomalaiset ja populismin retoriikka. Toimittaneet Emilia Palonen ja Tuija Saresma. Tampere: Vastapaino 2017. 
Phillips, Whitney. 2015. This is Why We Can't Have Nice Things: Mapping the Relationship Between Online Trolling and Mainstream Culture. Cambridge MA: The MIT Press.

Pullinen, Jussi. 2019. Huvittunut sivullinen syö naksuja. Helsingin Sanomat 15.12.2019. https://www.hs.fi/sunnuntai/art-2000006342832.html

Rajala, Tuomas. 2019. Sita Salminen tienaa sata tonnia kertomalla elämästään ja rapistelemalla mikrofonin ääressä. Op.media 5.9.2019. https://op.media/ teemat/ihmiset/sita-salminen-tienaa-sata-tonnia-kertomalla-elamastaanja-rapistelemalla-mikrofonin-aaressa-7998b9f933e3478189efd4ebe88c $\underline{\mathrm{d} 6 \mathrm{e} 2}$

Rautio, Samppa. 2019. Suomen virallisimmat aivo-orgasmit kuiskiva Osku häkeltyy, kun tuntemattomat pysäyttävät kadulla: "En mä vapaa-ajalla kuiski edes vaimolle". Iltalehti 5.4.2019. https://www.iltalehti.fi/kotimaa/a/28e121c5-a801-487a-8ff1-ac749bb7f831

Reinikainen, Hanna. 2018. Mikrovaikuttaja tuntuu samaistuttavalta. Alma Media 3.12.2018. https://www.almamedia.fi/uutishuone/ uutinen/03-12-2018-mikrovaikuttaja-tuntuu-samaistuttavalta

Rettberg, Jill W. 2014a. Seeing Ourselves Through Technology: How We Use Selfies, Blogs and Wearable Devices to See and Shape Ourselves. Hampshire/New York: Palgrave MacMillan.

Rettberg, Jill W. 2014b. Blogging, 2nd ed. Cambridge/Malden: Polity Press.

Räty, lida. 2019. "Nyt tuntuu, että entiseen ei ole paluuta". Terveysruokapuhe holistiseen hyvinvointiin tähtäävässä terveysruokakulttuurissa. Folkloristiikan pro gradu -tutkielma. Turun yliopisto. https://www.utupub.fi/bitstream/handle/10024/148000/Raty lida opinnayte.pdf? sequence $=1$ \&isAllowed $=\mathrm{y}$

Saarikoski, Petri, Jaakko Suominen, Riikka Turtiainen ja Sari Östman. 2009. Funetista Facebookiin - Internetin kulttuurihistoria. Helsinki: Gaudeamus.

Senft, Theresa ja Nancy Baym. 2015. "What Does the Selfie Say? Investigating a Global Phenomenon." International Journal of Communication 9(0): 1588-1606.

Shifman, Limor. 2014. Memes in Digital Culture. Cambridge MA: The MIT Press.

Suominen, Jaakko, Sari Östman, Petri Saarikoski ja Riikka Turtiainen. 2013. Sosiaalisen median lyhyt historia. Helsinki: Gaudeamus.

Tifentale, Alise, ja Lev Manovich. 2015. "Selfiecity: Exploring Photography and SelfFashioning in Social Media." Teoksessa Postdigital Aesthetics, toimittaneet, David Berry ja Michael Dieter, 109-122. London: Palgrave Macmillan.

Turtiainen, Riikka ja Sari Östman. 2009. "Tavistaidetta ja verkkoviihdettä: Omaehtoisten verkkosisältöjen tutkimusetiikkaa." Teoksessa Kulttuurituotanto: Kehykset, käytäntö ja prosessi, toimittaneet Maarit Grahn ja Maunu Häyrynen, 336-358. Helsinki: Suomalaisen Kirjallisuuden Seura.

Turtiainen, Riikka. 2016. "Naisjoukkueurheilijat sosiaalisessa mediassa: Sukupuolen, etnisyyden ja seksuaalisuuden esityksiä haastamassa." Teoksessa Urheilun takapuoli: Tasa-arvo ja yhdenvertaisuus liikunnassa ja urheilussa, toimittaneet Päivi Berg ja Maria Kokkonen, 111-137. Helsinki: Nuorisotutkimusseura.

Turtiainen, Riikka. 2017. "'Mentorina terveelliselle elämäntyylille': Asiantuntijuuden rakentuminen suomalaisten naisten fitnessblogeissa." Liikunta ja Tiede 54(1): 58-67.

Turtiainen, Riikka. 2019. "Leikitäänkö kampaajaa? Digitaalinen koskettaminen ASMRroolileikkivideoissa." Lähikuva 32(3): 26-45. 
Vainikka, Eliisa, Elina Noppari ja Janne Seppänen. 2017.“Exploring Tactics of Public Intimacy on Instagram." Participations, Journal of Audience \& Reception Studies 14(1): 108-128.

Valkama, Vanessa. 2018. Nimekkäät bloggaajat valjastettiin markkinoimaan Hämeenlinnaa asuinpaikkana. Hämeen Sanomat 26.11.2018. https://www.hameensanomat.fi/ kanta-hame/nimekkaat-bloggaajat-valjastettiin-markkinoimaan-hameenlinnaaasuinpaikkana-tama-on-ihan-uusi-karki-johon-en-ole-muualla-tormannyt-383723/

Östman, Sari 2007. "Nettiksistä Blogeihin: Päiväkirjat Verkossa." Tekniikan Waiheita 25(2): 37-57.

Östman, Sari. 2015. "Millasen päivityksen tästä sais?": Elämäjulkaisijuuden kulttuurinen omaksuminen. Jyväskylä: Jyväskylän yliopisto.

Filosofian tohtori, dosentti Kaarina Koski on koulutukseltaan folkloristi ja tutkii muun muassa kuolemaa, kansanuskoa, nykykulttuurin ilmiöitä ja vernakulaareja diskursseja. Hän työskentelee tällä hetkellä Helsingin yliopistossa yliopistotutkijana Pohjoiset painajaiset 1400-2020 -tutkimushankkeessa.

Filosofian tohtori, dosentti Riikka Turtiainen toimii digitaalisen kulttuurin yliopistonlehtorina Turun yliopistossa. Turtiaisen erityisosaamiseen kuuluvat verkkoaineistoihin liittyvä tutkimusetiikka ja -metodologia. Hän on kiinnostunut muun muassa kehollisen kokemuksen tarkastelusta digitaalisessa kontekstissa ja tutkii sosiaalista mediaa erityisesti urheilun ja sukupuolen yhteydessä. 